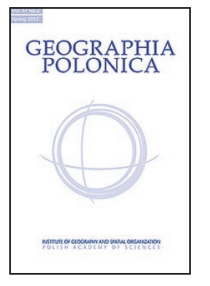

\title{
SPATIO-TEMPORAL ANALYSIS OF THE DEVELOPMENT OF THE COVID-19 EPIDEMIC (PANDEMIC) IN POLAND: FIRST PHASE OF DEVELOPMENT
}

\author{
Jerzy J. Parysek ${ }^{1}$ (D) Lidia Mierzejewska ${ }^{2}$ \\ Faculty of Human Geography and Planning \\ Adam Mickiewicz University in Poznań \\ B. Krygowskiego 10, 61-680 Poznań: Poland \\ e-mails: parys@amu.edu.pl ${ }^{1}$ • mierzeja@amu.edu.pl $\left.\right|^{2}$ (corresponding author)
}

\begin{abstract}
The purpose of this study is to present a description of the course of the COVID-19 epidemic in Poland in the space-time dimension in the period from March 15th to August 8th 2020. The result of the conducted research is a presentation of the regional differentiation of the course of the epidemic in Poland, the comparison of the intensity of SARS-CoV-2 infections in particular voivodeships, the determination of the degree of similarity in the course of the pandemic development process in individual regions (voivodeships) of the country, and also the indication of the factors which could be taken into account when attempting to explain the interregional differences in the course of the epidemic. The conducted research shows, among other things, that: (1) in terms of time, the development of the epidemic was generally monotonic, however the increase in new infections was rather cyclical, (2) in the spatial dimension, the development of the epidemic was rather random, although the greatest number of infections was characteristic of the most populated regions of the country, (3) the level of infections in Poland was mainly positively influenced by: population density, working in industry, people beyond retirement, age as well as a poorly developed material base of inpatient care.
\end{abstract}

\section{Key words}

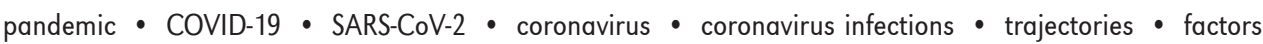
- regional variation - Poland

\section{Introduction}

In times of dynamic medical and pharmaceutical development when, at least in Europe, infectious diseases have been eliminated, mainly due to the widespread of preventive vaccinations and the improvement of sanitary hygiene, the SARS-CoV-2 virus appeared in Wuhan, China, which at an unprecedentedly rapid pace took over the whole world. The epidemics of infectious diseases, which have accompanied mankind probably since the dawn of time, have always had dangerous consequences for the inhabitants 
and civilization. These include depopulation of countries and regions, the collapse of economies with consequences such as hunger, malnutrition, unemployment, wars, fear about the future, also crime, disintegration of population services, breaking social ties, etc. Diseases and epidemics have, at the same time, been the driving force of the development of science, especially medicine, including virology, epidemiology and pharmacology. All these long known effects of epidemic development are fully visible in this latest pandemic, the course, duration as well as the immediate and long-term consequences of which, are difficult to predict.

The purpose of this study is to present a description of the course of the COVID-19 epidemic (pandemic) in Poland in the spacetime dimension in the period from March 15th to August 8th 2020. In concrete terms, this means a description of the development and spread of the epidemic in time and space, which is important, for instance, due to the fact that, one feature of the reality we live in, is the variability in time (chronology) and space (chorology) of things, events and processes which we are participants of. There is also no doubt that the event of the appearance of the SARS-CoV-2 virus quickly transformed into a spatial diffusion process and spread worldwide.

The literature concerning various aspects of the SARS-CoV-2 coronavirus and the development of the COVID-19 pandemic is exceptionally reach. What dominates, however, is the publications dedicated to the medical, and specifically virological, epidemiological, metabolic and immunological side of the issue. There are only single publications (mainly online) which allow for geographical aspects of the development and spread of the COVID-19 infection. The studies concerning spatial and temporal analysis of the pandemic development, however, were not found. This also includes the lack of works that would reconstruct the pandemic development process in time and space using spatial diffusion models, which is understandable when the knowledge of this particular virus and of both medical and socio-economic factors that contribute to its spreading, is still insufficient. However, it does not mean that there is no search for such factors and no analysis of their geographical differences (Jarynowski et al., 2020; Nicola et al., 2020; Sun et al., 2020; Śleszyński, 2020; Zhang \& Schwartz, 2020). What is particularly interesting is the issue of distance as a factor affecting the diffusion of infections (Fuchs, 2020). There are also comprehensive studies showing the geographical context of the epidemic, which is reflected in the analysis of geographical differences of such elements of the widely understood issue as: infection, vulnerability, interdependency, immunization, resilience, blame and health care (Sparke, Angulelov 2020). There are few Polish publications considering the geographical aspects of the development of the epidemic in Poland (with a relatively large number of works in the field of medicine, epidemiology, virology and sanitary protection). One can mention attempts to determine the influence of widely understood mobility on epidemic development (Jarynowski et al. 2020) and search for spatial regularities in the spread of SARSCoV-2 coronavirus infections in Poland in the first 100 days of the epidemic (Śleszyński, 2020). In this context the article is, in a sense, a pioneering one perhaps not only nationwide, taking account of the multifaceted development of the epidemic in terms of time and space, in the first phase of its growth, using an original and little-known research method (the trajectory of development, called a connected scatterplot in the source literature).

\section{The spread of the COVID-19 pandemic as a space-time diffusion of a specific 'innovation'}

In the 1960s, there was a serious interest in spatial processes, especially in spatial diffusion, and specifically in innovation, which became possible due to the development of computer science and computational techniques. The basic problem of 'diffusion' 
research was to build a model of the spread of innovation in a specific area (Hägerstrandt, 1968; Haggett, 1965; Haggett et al., 1977; Pred, 1977; Łoboda, 1983; Kamiński, 1982; Domański, 1982, 1990a, 1990b; Parysek, 1997, 2006). A certain kind of 'innovation', as it seems, would be the appearance of an infectious disease (viral, bacterial), whereas a spatial diffusion, would be its spread. The COVID-19 pandemic is therefore, to some extent, a typical, yet also specific process of spatial, or in fact, space-time diffusion. It should be emphasized here that the Swedish geographer T. Hägerstrandt based his thoughts on spatial diffusion on the study of such an 'innovation' as bovine tuberculosis caused by Mycobacteriuum bovis (Hägerstrandt, 1968; Pred, 1977). It can therefore be assumed, that he played a significant role in the development of veterinary and epidemiological research (Corner 1994).

There are many models of spatial diffusion processes, and the most classic of these include expansion and relocation diffusion. Moreover, each of these diffusions can be either transmittable (epidemic) or hierarchical (cascade). It seems that the diffusion of the SARS-CoV-2 coronavirus is of a expansion, transmissive diffusion nature, although it also shows symptoms of relocation diffusion. In expansion diffusion, the transmission process takes place from one place to the adjacent places. In the case of a virus, from one individual (person) to another (other individuals). In classical expansion diffusion, the transmission process can be stopped, accelerated or multiplied within one individual. The first case, containment, can only be considered in the case of successful isolation of the infected person (quarantine). In expansion, transmissive diffusion, specifically epidemic diffusion, the development and course of the diffusion process occurs through direct contact. Practically, in a centrifugal way, from person, carrier of the virus, to other people, who in turn, either become infected or show immunity to infection. Immunity may be conditioned by various factors. As the current course of the pandemic shows, on the one hand, the diffusion process is inhibited when being protected from infection, which is facilitated by staying at home (avoiding contact), using a mask, social distancing, washing and disinfecting hands, as well as young age, one's health condition and resistance. When analyzing the diffusion process of the SARSCoV-2 coronavirus, it should also be borne in mind that the diffusion process does not follow Pascal's rules, i.e. the same in all directions and with the same intensity, which results in the temporal and spatial differentiation of epidemic processes. In the literature on spatial diffusion (innovation), there are a number of barriers which inhibit or even prevent the course of the diffusion process, e.g. suppressing (absorbing) barriers, which do not allow for new contact and stop the diffusion process, absorbing barriers, which admittedly also, do not allow for new contact, but at the same time do not eliminate diffusion channels, reflecting barriers, which absorb a given contact, yet at the same time make it possible to establish a different contact in its place, and directly reflecting barriers, which do not absorb the contact, but reflect it randomly to other possible adapters. However, it seems that in the case of epidemics, their significance is not great. According to the current state of knowledge, the risk of contracting a virus is determined by, as is currently the case, direct contact, and only isolation can prevent new infections (Kretowicz, 2013; Śleszyński, 2020). Of course, infected people, even if they do not show any sign of symptoms, may infect others and 'act' as reflective barriers.

\section{Research procedure}

Although the purpose of this study is to present the results of the space-time analysis of the development of the COVID-19 pandemic in Poland in the initial period of its development, it will not include the modeling of the diffusion process, mainly due to the large number of unknown factors determining the spatial diffusion of this disease, as well as the lack of the necessary numerical 
data and the undeniable problems related to the selection of the model and modeling technique. In other words, the present text presents a multifaceted reconstruction of the disease development process understood rather in a traditional way. The research will not result in building a diffusion model.

The research was based on a collection of data on the SARS-CoV-2 virus infections in Poland in 16 regions (voivodeships, Fig. 1). The applied graphical method of research (development trajectories), however, forced (for the sake of clarity of presentation) a resignation in keeping daily records of infections. Data, recording the epidemic development process in consecutive five-day periods (pentads), starting from March 15th, 2020, was used. This data was summarized in a base table, in which the rows represented Poland as a whole, and the aforementioned 16 regions (17 rows in total), whereas the columns represented the number of cases in the five-day periods - pentads (29 columns). The data used in the conducted research was collected and systematically compiled by Rogalski et al. (2020). The set of consecutive pentads made it possible to take into account the chronological (time) aspect, albeit not continuously, day-today, and the 16 regions - the chorological (spatial) analysis of the spatio-temporal development of the epidemic.

As it has already been written, the basic method of studying the regional differentiation of the epidemic involved plotting, the socalled development trajectory of the development of SARS-CoV-2 infections for Poland as a whole, and for each region, while using the compiled time series of data. Trajectory is a ballistics term which describes the path a projectile travels from the moment it is launched, to the moment it reaches its target. Referring to the significance of this concept, a linear diagram of the changes which have taken place in subsequent time cuts (specifically in pentads) may be considered a graphical representation of the development

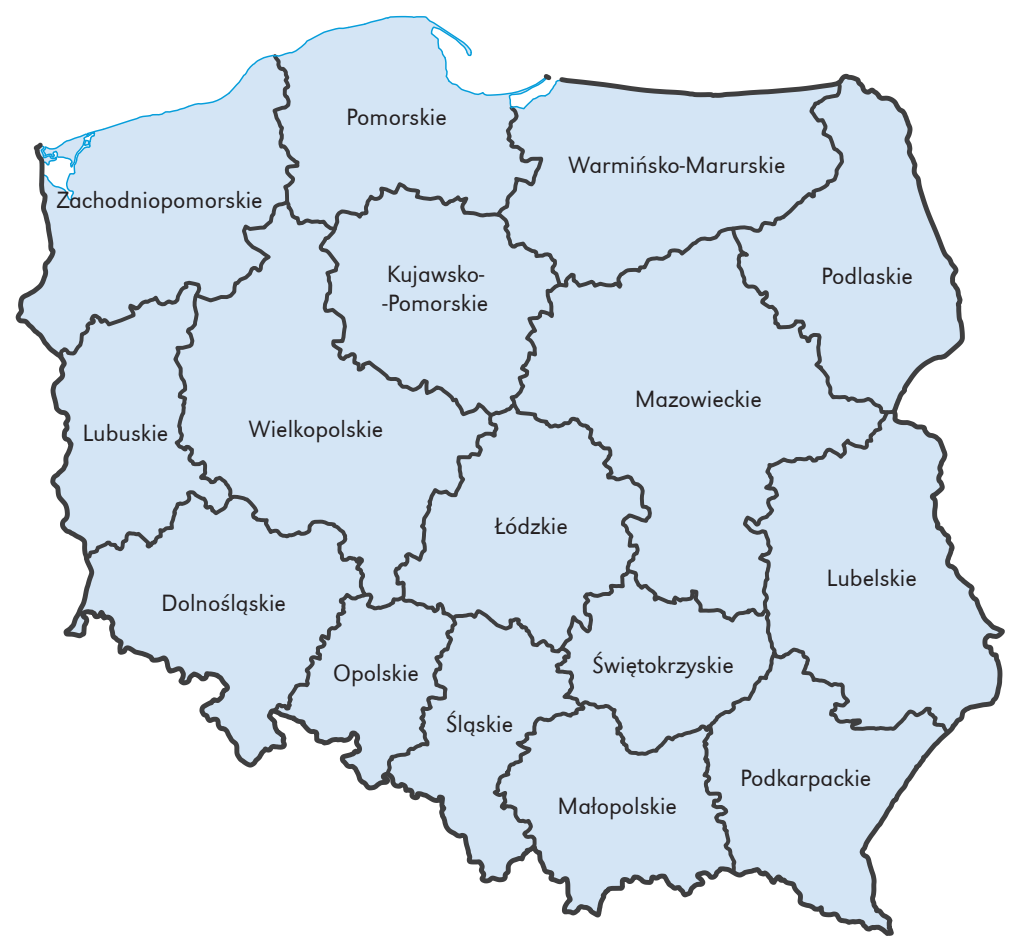

Figure 1. Administrative division of Poland (regions / voivodeships) 
of a phenomenon in the period in question. The trajectory, known in English literature as connected scatter plot, is however, a specific plot, fundamentally different from traditionally used line plots. The trajectory (development) chart uses a seemingly illogical solution. In the system of rectangular coordinates, in terms of points, it is not the the size of a given phenomenon which is presented in consecutive time cuts (most often in years), as is the case with typical line graphs, but the changes which have taken place over a certain period of time. And so, the phenomenon in the current period is marked on the $x$ axis $(\mathrm{t})$, whereas the phenomenon in the previous period is marked on the y axis $\left(t_{p}\right)$. In this study, it is the current pentad and the previous pentad, respectively. The next points in the rectangular coordinate system will therefore be the changes which have taken place in the subsequent pentads. The trajectory describing the development (change) process is a curved line, connecting successive points from the initial to the final pentad of the research period. The subsequent points on the trajectory show the changes which have occurred after the next pentad. The trajectory may take various forms. The interpretation of the course of the trajectory should be carried out with reference to the starting point of the $x$ and $y$ axes, the course of the trajectory shape and the distance between successive points. A trajectory line (or its section) close to a straight line indicates a monotonic increase or decrease in the number of cases. The shorter the distance of the trajectory point from the origin of the coordinate system, the less infections the are, the longer the distance, the more infections there are. The coordinates of the consecutive trajectory points indicate the number of infections: $x$ - in the current pentad (on a given day), $y$ - in the previous pentad. The loop in the trajectory indicates a return to the situation which has already taken place, while the looping (several loops of various sizes) indicates an unstable situation, the cyclical nature of the process, and the lack of a clear tendency in development. The return to the starting point of the system suggests a gradual extinction of the epidemic, while the receding points indicate its development. The distance between the successive points of the trajectory illustrates the scale of the changes which took place after another pentad which was taken into account. The greater the distance, the greater the changes. The course of the line (trajectory) is therefore, a synthetic picture of the transition from the initial state to the final state of the studied process, in this case the initial phase of the epidemic (Ormerod, 1993; Hingel, 1993; Parysek, 2002, 2004). This very interesting and valuable method of studying development, and overall process, is not used very often. However, such examples can be found in Polish geographic research (Parysek, 2002, 2004; Parysek \& Mierzejewska, 2012). In this particular case, as already mentioned, the trajectories were plotted for the number of infections recorded in consecutive five-day periods, and not in consecutive days. This was primarily dictated by interpretative reasons. A generalized image of the ongoing process was obtained, which would not have been ensured by plotting a trajectory with the day-to-day changes (very many points close to each other). A weakness of this approach is the fact that, it does not take into account the changes which occur on a day-to-day basis, the more so because the differences, as shown by the source data, were sometimes big.

The intensity of SARS-CoV-2 infections in all the voivodeships was also compared, and the appropriate classification was made. The basis for the classification was a cumulatively defined level of infections, compared to the number of inhabitants, in five selected time cuts (monthly). Categories of differentiated levels have been separated taking into account the mean value and the standard deviation, according to the proposal of Hellwig (1966). Moreover, the degree of differentiation of the epidemic development process in individual voivodeships has been determined, specifically the relativized variance in the number of cases (coefficient of variation), also for time cuts of every five days. 
What also seemed interesting was determining the degree of similarity in the course of the pandemic development process in the individual regions (voivodeships) of the country, which was made possible by the correlation analysis. The correlation coefficient is a frequently used similarity function of the compared objects (Lance \& Williams, 1966; Steinhausen \& Langer, 1977; Parysek, 1982). In this case, the objects were the regions, and the properties were the infections in the compiled time series (after each pentad). The voivodeships were compared in two perspectives, by calculating the correlation coefficients for (1) the development process (the state of infection at the end of each pentad) and (2) the increase in infections in individual pentads. The categories of voivodeships of similar epidemic patterns were distinguished using the method of elementary connections (dual between "closest neighbors"), and Pearson's correlation coefficient was the function of similarity.

Moreover, attempts have been made to indicate the influence of factors which could be taken into account when trying to explain the interregional differences in the course of the epidemic, and more specifically, the differentiation of the level of infections. To achieve this goal, a multivariate regression analysis was used, with the subsequent elimination of the least significant variables. The variables which, theoretically may indicate a greater possibility of interpersonal contact, as well as susceptibility to infection and illness, and the possibility of obtaining medical help were taken into account. This type of research has recently been undertaken in various perspectives, by various research teams (Jarynowski et al., 2020, Mellacher, 2020, Pisano, 2020).

\section{Virus infections - general description}

In the public space, the data of the Ministry of Health which appear most often is that, of the number of infections on a given day and cumulatively up to a given day since the beginning of the epidemic. Until August 7th 2020, 50324 cases of SARS-CoV-2 infection were registered in Poland. The development of the epidemic was generally monotonic, yet with a diversified number of new infections each day and in the pentads, which were, as already mentioned, the basis for the analysis of the process in this study. However, the increases of new infections were not monotonic, but rather periodic (cyclical). The periods of increase in the number of new infections were separated by periods of decline, falling on April 9th - 24th, April 19th - May 4th, May 14th - May 19th, May 24th - June 3rd, June 8th - 16th and 19th - 28th, and July 3rd - 7 th. From July 13 th, the number of new cases grew monotonically, reaching 3430 new infections in the pentad on August 2nd-7th. Both the overall, cumulative number of infections, as well as the increases, were different in particular voivodeships.

However, the dynamics of the increase in infections shows a steadily decreasing tendency, which is not without significance, on the one hand, due to the quite dynamic beginning of the epidemic, and on the other hand, due to the size of infections. This dynamics, in monthly intervals, amounted to $612 \%$, $184 \%, 146.4 \%$ and $129.5 \%$, respectively.

Out of the total number of 2055 infections on March 30th, 23.7\% were in the Mazowieckie Voivodeship, $12.6 \%$ in the Dolnoślaskie Voivodeship, $10.2 \%$ in the Ślaskie Voivodeship, $9.8 \%$ in the Łódzkie Voivodeship and $8.5 \%$ in the Małopolskie Voivodeship. On April 29th, the situation was as follows: out of the total number of 12,577 infections, 19.3\% were in the Mazowieckie Voivodeship, $17.4 \%$ in the Ślaskie Voivodeship, 12.1\% in the Dolnoślaskie Voivodeship, $11.2 \%$ in the Wielkopolskie Voivodeship and $7.4 \%$ in the Małopolskie Voivodeship. On May 29th, compared to April 29th, there were significant changes in the distribution of infections in individual voivodeships. The number of infections in the Ślaskie Voivodeship increased significantly, which increased the share of this region in the country to the level of $34.2 \%$. The share of the following voivodeships 
relatively decreased: the Mazowieckie Voivodeship - 15.1\%, the Dolnośląskie Voivodeship - 11\%, the Wielkopolskie Voivodeship - 9.3\% and the Łódzkie Voivodeship - 6.4\%. This tendency was strengthened in the next time cut, i.e. on June 28th, when the Ślaskie Voivodeship had $36.9 \%$ of total infections on a national scale, and in the following voivodeships: the Mazowieckie Voivodeship - 14.7\%, the Łódzkie Voivodeship - 9.1\%, the Dolnośląskie Voivodeship - 8,6\% and the Wielkopolskie Voivodeship 7.7\%. On July 28th, the share of voivodeships in the total number of infections in the country was as follows: the Ślaskie Voivodeship - 35.5\%, the Mazowieckie Voivodeship - 14.1\%, the Łódzkie Voivodeship - 8.8\%, the Wielkopolskie Voivodeship - $8.3 \%$ and the Dolnoślaskie Voivodeship $7.3 \%$ (Tab. 1). The level of infection concentration also changed in the five most significant voivodeships, which amounted to $64.8 \%$,
$67.3 \%, 76.0 \%, 77.0 \%$ and $74.0 \%$, respectively, generally increasing. The number of infections, however, relates to the population, and to a much lesser extent to the population density of the voivodeships (Tabs. 1 and 2). In other words, there is a noticeable logical relationship: the more inhabitants in the voivodeship, the greater the number of infections.

\section{Differentiation of the virus infection spread}

Although, as it has already been written, the Ministry of Health, as part of its messages on the state of the epidemic, mainly provides the number of infections in a given voivodeship from the beginning of the epidemic and the number of new infections in the following days, the state of the epidemic threat, and specifically the intensity of the epidemic, is mainly indicated by infection rates related

Table 1. The spread of the epidemic from a regional perspective in Poland in the period between March 30th - July 28th 2020.

\begin{tabular}{|c|c|c|c|c|c|c|c|c|c|}
\hline \multirow{3}{*}{$\begin{array}{c}\text { Regions } \\
\text { (voivodeships) }\end{array}$} & \multicolumn{9}{|c|}{ The number of infections as of: } \\
\hline & \multicolumn{2}{|c|}{30.03} & \multicolumn{2}{|c|}{20.04} & \multicolumn{2}{|c|}{29.05} & \multicolumn{2}{|c|}{28.06} & \multirow{2}{*}{28.07} \\
\hline & number & $\%$ & number & $\%$ & number & $\%$ & number & $\%$ & \\
\hline Poland & 2,055 & 100.0 & 12,577 & 100.0 & 23,153 & 100.0 & 33,907 & 100.0 & 43,904 \\
\hline Dolnośląskie & 258 & 12.6 & 1,520 & 12.1 & 2,556 & 11.0 & 2,910 & 8.6 & 3,201 \\
\hline Kujawsko-Pomorskie & 72 & 3.5 & 537 & 4.3 & 593 & 2.6 & 669 & 2.0 & 754 \\
\hline Lubelskie & 114 & 5.5 & 358 & 2.8 & 485 & 2.1 & 641 & 1.9 & 925 \\
\hline Lubuskie & 36 & 1.8 & 87 & 0.7 & 114 & 0.5 & 149 & 0.4 & 370 \\
\hline Łódzkie & 202 & 9.8 & 936 & 7.4 & 1,488 & 6.4 & 3,086 & 9.1 & 3,853 \\
\hline Małopolskie & 174 & 8.5 & 876 & 7.0 & 1,199 & 5.2 & 1,685 & 5.0 & 3,223 \\
\hline Mazowieckie & 487 & 23.7 & 2,427 & 19.3 & 3,494 & 15.1 & 4,975 & 14.7 & 6,181 \\
\hline Opolskie & 54 & 2.6 & 391 & 3.1 & 631 & 2.7 & 932 & 2.7 & 1,146 \\
\hline Podkarpackie & 80 & 3.9 & 328 & 2.6 & 382 & 1.6 & 635 & 1.9 & 1,207 \\
\hline Podlaskie & 36 & 1.8 & 367 & 2.9 & 445 & 1.9 & 806 & 2.4 & 955 \\
\hline Pomorskie & 48 & 2.3 & 424 & 3.4 & 552 & 2.4 & 657 & 1.9 & 847 \\
\hline Ślqaskie & 209 & 10.2 & 2,182 & 17.3 & 7,919 & 34.2 & 12,524 & 36.9 & 15,597 \\
\hline Świętokrzyskie & 37 & 1.8 & 266 & 2.1 & 439 & 1.9 & 776 & 2.3 & 956 \\
\hline Warmińsko-Marurskie & 57 & 2.8 & 144 & 1.1 & 179 & 0.8 & 240 & 0.7 & 343 \\
\hline Wielkopolskie & 132 & 6.4 & 1,414 & 11.2 & 2,145 & 9.3 & 2,612 & 7.7 & 3,641 \\
\hline Zachodniopomorskie & 59 & 2.9 & 380 & 3.0 & 531 & 2.3 & 609 & 1.8 & 70 \\
\hline
\end{tabular}

Source: own study based on data from Rogalski et al. (2020). 
Table 2. The intensity of SARS-CoV-2 infections in Poland per 10 thousand inhabitants by region in the period between March 30th - July 28th 2020

\begin{tabular}{|l|c|c|c|c|}
\hline \multirow{2}{*}{$\begin{array}{c}\text { Regions } \\
\text { (voivodeships) }\end{array}$} & \multicolumn{4}{|c|}{ Cumulative number of cases as of: } \\
\cline { 2 - 5 } & 30.03 & 20.04 & 29.05 & 28.06 \\
\hline Poland & 0.5350 & 3.2743 & 6.0277 & 8.8274 \\
\hline Dolnoślqskie & 0.8893 & 5.2392 & 8.8101 & 10.0302 \\
Kujawsko-Pomorskie & 0.3465 & 2.5845 & 2.8540 & 3.2198 \\
Lubelskie & 0.5383 & 1.6906 & 2.2903 & 3.0270 \\
Lubuskie & 0.3548 & 0.8575 & 1.1237 & 1.4686 \\
Lódzkie & 0.8190 & 3.7951 & 6.0333 & 12.5126 \\
Małopolskie & 0.5117 & 2.5760 & 3.5259 & 4.9550 \\
Mazowieckie & 0.9013 & 4.4916 & 6.4663 & 9.2071 \\
Opolskie & 0.5474 & 3.9635 & 6.3963 & 9.4475 \\
Podkarpackie & 0.3758 & 1.5406 & 1.7943 & 2.9826 \\
Podlaskie & 0.3047 & 3.1061 & 3.7663 & 6.8216 \\
Pomorskie & 0.2057 & 1.8170 & 2.3655 & 2.8155 \\
Ślqskie & 0.4610 & 4.8130 & 17.4675 & 27.6251 \\
Świętokrzyskie & 0.2980 & 2.1425 & 3.5359 & 6.2503 \\
Warmińsko-Marurskie & 0.3989 & 1.0077 & 1.2526 & 1.6795 \\
Wielkopolskie & 0.3778 & 4.0470 & 6.1392 & 7.4757 \\
Zachodniopomorskie & 0.3468 & 2.2339 & 3.1216 & 3.5802 \\
\hline
\end{tabular}

Source: own study based on data from Rogalski et al. (2020).

to the number of inhabitants of particular voivodeships. The relevant indicators, i.e. the number of infected per 10,000 inhabitants, were calculated for five monthly time cuts on: March 30th, April 29th, May 29th, June 28th and July 28th 2020 (Tab. 2). These indicators were the basis for the classification of voivodeships in terms of infection intensity. Classes of different intensity of infections were marked out taking into account the mean and standard deviation, as proposed by Hellwig (1968). There are three classes of intensity: (1) low, (2) average and (3) high. ${ }^{1}$

The classification of the diverse infection intensity in the voivodeships on March 30th was as follows: Class I - low intensity voivodeships: Kujawsko-Pomorskie, Lubuskie, Podkarpackie, Podlaskie, Pomorskie, Świętokrzyskie, Wielkopolskie and Zachodniopomorskie;

\footnotetext{
1 The distribution of cases significantly deviates from the normal distribution, thus making it impossible to distinguish five classes.
}

Class II - medium intensity voivodeships: Małopolskie, Opolskie, Ślaskie, Lubelskie and Warmińsko-Marurskie; Class III - high intensity voivodeships: Dolnośląskie, Łódzkie and Mazowieckie. Thus, the intensity was lower in the voivodeships of north-western and eastern Poland, and greater in south-western and central Poland (Fig. 2).

The classification of the diverse intensity of infections on April 29th was as follows: Class I - low intensity: voivodeships: Lubelskie, Lubuskie, Podkarpackie, Pomorskie, Świętokrzyskie, Warmińsko-Mazurskie and Zachodniopomorskie; Class II - average intensity of infections: voivodeships: Małopolskie and Kujawsko-Pomorskie; Class III high intensity of infections: voivodeships: Dolnoślaskie, Łódzkie, Mazowieckie, Opolskie, Podlaskie, Ślaskie and Wielkopolskie. The last of the above-mentioned classes covered almost half of all voivodeships (7 out of 16), arranged in the shape of a wedge, taking the direction from south-west to north-east 
(Fig. 3). The voivodeships of north-western and south-eastern Poland were affected to a much lesser extent by the pandemic.

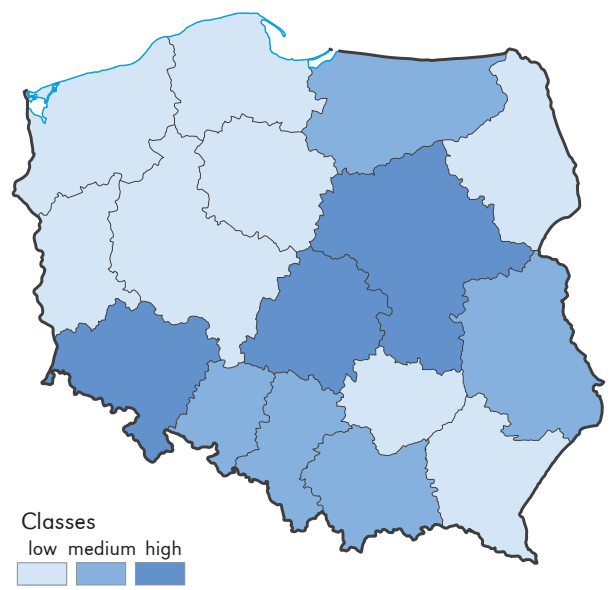

Figure 2. Regional differentiation in the intensity of Sars-CoV-2 infections in Poland on March 30th 2020

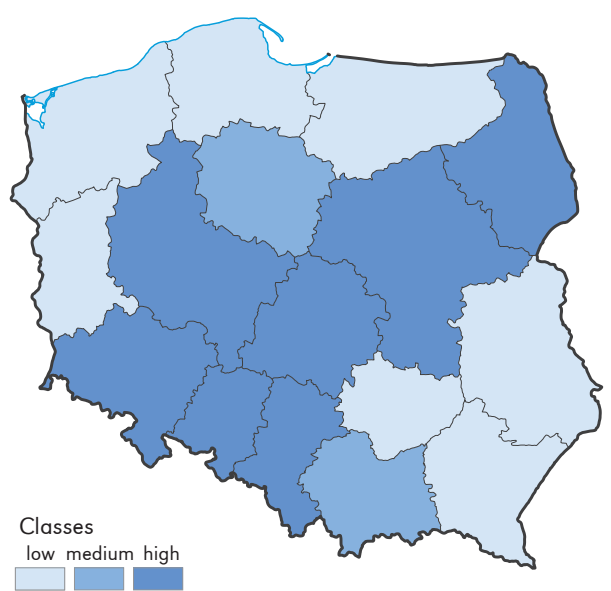

Figure 3. Regional differentiation in the intensity of Sars-CoV-2 infections in Poland on April 29th 2020

For the date of May 29th, the following classification of voivodeships was obtained from the point of view of diversifying the intensity of infections: Class I - low intensity: voivodeships: Kujawsko-Pomorskie, Lubelskie, Lubuskie, Podkarpackie, Pomorskie and Warmińsko-Marurskie; Class II - average intensity of infections: voivodeships: Łódzkie, Małopolskie, Mazowieckie, Opolskie, Podkarpackie, Świętokrzyskie, Wielkopolskie and Zachodniopomorskie; Class III - high intensity: voivodeships: Dolnośląskie and extremely high - Ślqskie. Thus, the high intensity of infections covered the region of south-western Poland, namely Śląsk (Fig. 4). The remaining regions were affected to a much lesser extent by the pandemic.

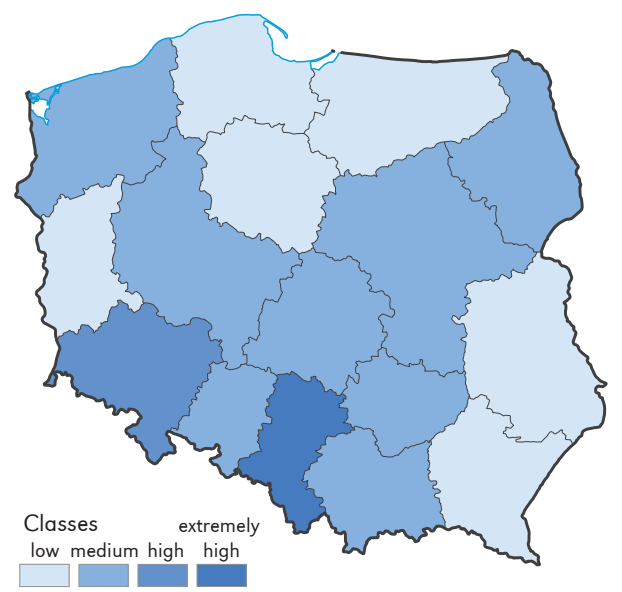

Figure 4. Regional differentiation in the intensity of Sars-CoV-2 infections in Poland on May 29th 2020

The classification of the diverse intensity of infections in the voivodeships on June 28th was as follows: Class I - low intensity: voivodeships: Kujawsko-Pomorskie, Lubelskie, Lubuskie, Podkarpackie, Pomorskie, Warmińsko-Mazurskie and Zachodniopomorskie; Class II - average intensity: voivodeships: Dolnośląskie, Małopolskie, Mazowieckie, Opolskie, Podlaskie, Świętokrzyskie and Wielkopolskie; Class III - high intensity: voivodeships: Łódzkie and Ślaskie. At the end of June, the situation in individual voivodeships slightly changed compared to the previous month (Fig. 5). A lower intensity of infections was recorded in the voivodeships of northern, western and eastern Poland, and greater - in central and southern Poland.

The classification of the diverse intensity of infections in the voivodeships on July 28th 


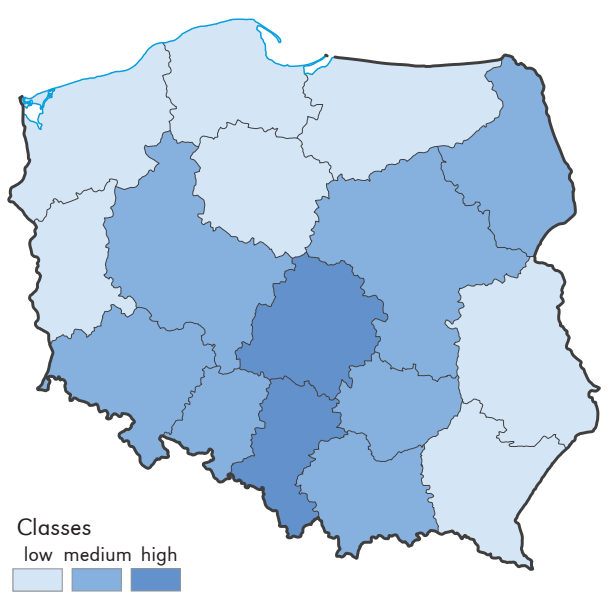

Figure 5. Regional differentiation in the intensity of Sars-CoV-2 infections in Poland on June 28th 2020

led to the following results: Class I - low intensity: voivodeships: Kujawsko-Pomorskie, Lubelskie, Lubuskie, Podkarpackie, Pomorskie, Warmińsko-Marurskie; Class II - average intensity of infections: voivodeships: Dolnoślaskie, Małopolskie, Mazowieckie, Opolskie, Podlaskie, Świętokrzyskie, Wielkopolskie and Zachodniopomorskie; Class III - high intensity: voivodeships: Łódzkie and Śląskie (extremely high intensity). Thus, the situation was very similar to the one at the end of June (Fig. 6). The only change took place in the Zachodniopomorskie Voivodeship, and specifically, it deteriorated slightly.

These classifications are selective, relative, because they result from the situation recorded on a given day, and this changes by the day.

In the light of the classifications made, it is possible to identify certain trends in the intensity of infection with the SARS-CoV-2 virus. And so: a constant level of low infection intensity in the period from March 30th - July 28th is shown in the following voivodeships: Lubuskie, Podkarpackie and Pomorskie, and to a lesser extent the Kujawsko-Pomorskie, Lubelskie and the Warmińsko-Mazurskie voivodeships. On the other hand, the average level of infections during the study period is maintained in the Less Poland Voivodeship,

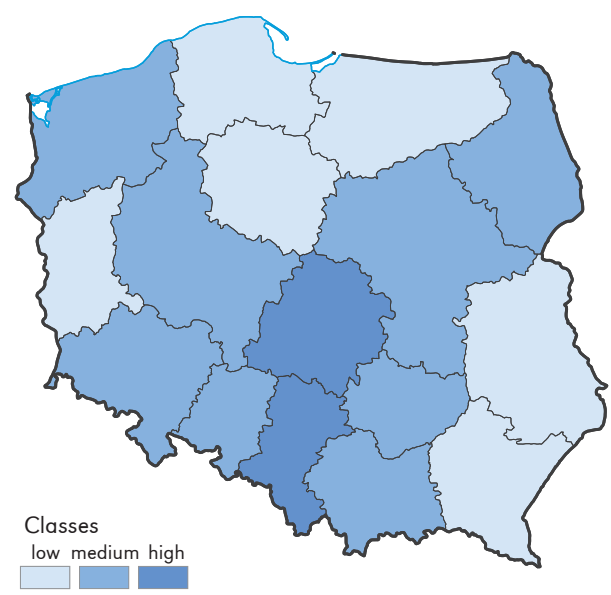

Figure 6. Regional differences in the intensity of Sars-CoV-2 infections in Poland on July 28th 2020

while the high level, in general in the Ślqskie and Łódzkie voivodeships. In the Dolnoślaskie and the Mazowieckie voivodeships, there is a noticeable decrease in the intensity of infections and their stabilization at an average level, as is the case in the following voivodeships: Opolskie, Podlaskie and Wielkopolskie. In the Zachodniopomorskie Voivodeship the intensity changes alternately from low to average. Taking into account the current course of the epidemic and the state of infections on July 28th, the epidemic in the Ślaskie and Łódzkie voivodeships constitutes a very serious problem, while the epidemic in Dolnoślaskie, Mazowieckie, Opolskie, Podlaskie, Świętokrzyskie, Wielkopolskie and Zachodniopomorskie voivodeships constitutes a serious problem. The highly random (in terms of spatial dimension) development of the epidemic, resulting from the conducted research, does not allow to formulate any reliable forecasts, although the situations conducive to infection, as well as the behavior of the inhabitants may lead to a change in the described state in the future.

As it has been said lately: the situation is dynamic. Such nature of the epidemic is indicated by the variance in the variability of the state of infections at the end of each pentad in the period from March 15th to August 
7th, 2020. During this period, the relatively defined variance (coefficient of variation) changed across 16 regions from $45.6 \%$ in the Kujawsko-Pomorskie Voivodeship to $80.7 \%$ in the Lubuskie Voivodeship, with the national value being $66.9 \%$.

The coefficient of variation was the basis for determining the differentiation in the dynamics of epidemic development in the individual voivodeships. Five classes of dynamics have been distinguished. ${ }^{2}$

Class I - very stable development dynamics is presented in the following voivodeships: Dolnośląskie, Kujawsko-Pomorskie, Warmińsko-Mazurskieand Zachodniopomorskie; Class II - stable dynamics is presented in the following voivodeships: Lubelskie, Mazowieckie and Pomorskie; Class III - average stability of dynamics is presented in the following voivodeships: Opolskie, Podlaskie, Świętokrzyskie and Wielkopolskie; Class IV - unstable dynamics, voivodeships: Łódzkie and Małopolskie; Class $V$ - very unstable dynamics is presented in the following voivodeships: Lubuskie, Podkarpackie and Śląskie (Fig. 7).

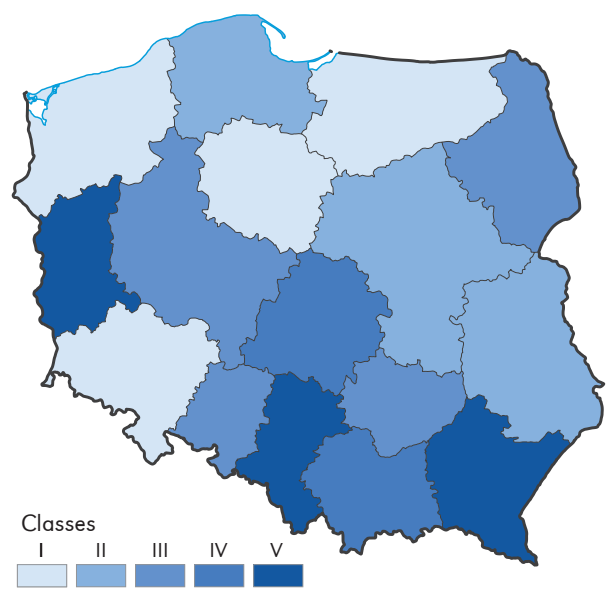

Figure 7. Regional differentiation in the dynamics of the spread of the Sars-CoV-2 epidemic in Poland between March 15th - August 7th 2020

2 The following class ranges have been adopted: Class I - CV below 54.9\%, Class II - CV from 55.0\% to $60.9 \%$, Class III - CV from $61 \%$ to $69.9 \%$, Class IV - CV from $70 \%$ to $75.9 \%$ and Class V - CV over $75.9 \%$.
This classification shows no correlation, either with the size of infections or their severity, and is extremely random in nature.

\section{Trajectories of the epidemic}

The research on the epidemic development process covered the period from March 15th to August 7th, 2020 and was conducted for pentads. March 15th can be considered conventionally the beginning of the epidemic. Only 125 infections were found throughout the country. In two voivodeships: Kujawsko-Pomorskie and Podlaskie no cases of infection were recorded, in Małopolskie - 1 case, and in Lubuskie and Pomorskie, 2 cases each. It should be added here that the first case (the so-called patient no. 1) was diagnosed in the Lubuskie Voivodeship (bordering on Germany).

Until March 20th 2020, the number of infections in Poland increased to 300 people and more systematically, however it increased in a wavy and cyclical manner. Until April 19th, it continued to increase monotonically, reaching the level of 2022. After that, it started decreasing, only to again exceed the value of 2000 on May 24th (2021) and June 8th (2473). The period between April 19th and June 8th can be described as the stabilization of the epidemic, followed by its gradual, yet as it turned out, shortterm extinction. Unfortunately, on July 13th, a new increase in the number of infections was recorded (1501), with a dynamic increase in the intensity (up to 3430 on August 7th). This tendency may indicate the transition to the next phase of the epidemic development (Fig. 8). The average level of infections during the study period, i.e. from March 15th to August 7th, was 22,489, with a standard deviation of 15,037 and a coefficient of variation of $66.9 \%$ (Tab. 3 ).

The course of infections in the Dolnoślaskie Voivodeship was slightly different from the national one. First, there was an undisturbed increase in the number of infections, reaching a maximum on April 19th (285 infections), followed by a gradual, relatively 
Table 3. Statistical description of the process of epidemic development in the regions of Poland in the period between March 15th - August 7th 2020 (calculated for pentads)

\begin{tabular}{|l|r|r|r|r|}
\hline \multicolumn{1}{|c|}{$\begin{array}{c}\text { Regions } \\
\text { (voivodeships) }\end{array}$} & Mean & $\begin{array}{c}\text { Standard } \\
\text { deviation }\end{array}$ & $\begin{array}{c}\text { Coefficient } \\
\text { of variation }\end{array}$ & Median \\
\hline Poland & 26,621 & 13,278 & 66.9 & 23,920 \\
\hline Dolnoślqskie & 2,353 & 859 & 54.6 & 2,603 \\
Kujawsko-Pomorskie & 590 & 173 & 45.6 & 594 \\
Lubelskie & 566 & 260 & 58.7 & 496 \\
Lubuskie & 173 & 124 & 80.7 & 124 \\
tódzkie & 2,192 & 1236 & 72.8 & 1,764 \\
Małopolskie & 1,676 & 1047 & 75.4 & 1,323 \\
Mazowieckie & 3,980 & 1706 & 58.2 & 3,591 \\
Opolskie & 719 & 330 & 63.7 & 658 \\
Podkarpackie & 617 & 401 & 77.2 & 398 \\
Podlaskie & 595 & 277 & 63.8 & 491 \\
Pomorskie & 569 & 242 & 58.7 & 556 \\
Śląskie & 8,989 & 5321 & 78.9 & 8293 \\
Świętokrzyskie & 567 & 295 & 69.0 & 491 \\
Warmińsko-Marurskie & 216 & 96 & 54.7 & 180 \\
Wielkopolskie & 2,311 & 1035 & 62.7 & 2,175 \\
Zachodniopomorskie & 522 & 181 & 51.9 & 540 \\
\hline
\end{tabular}

Source: own study based on data from Rogalski et al. (2020).

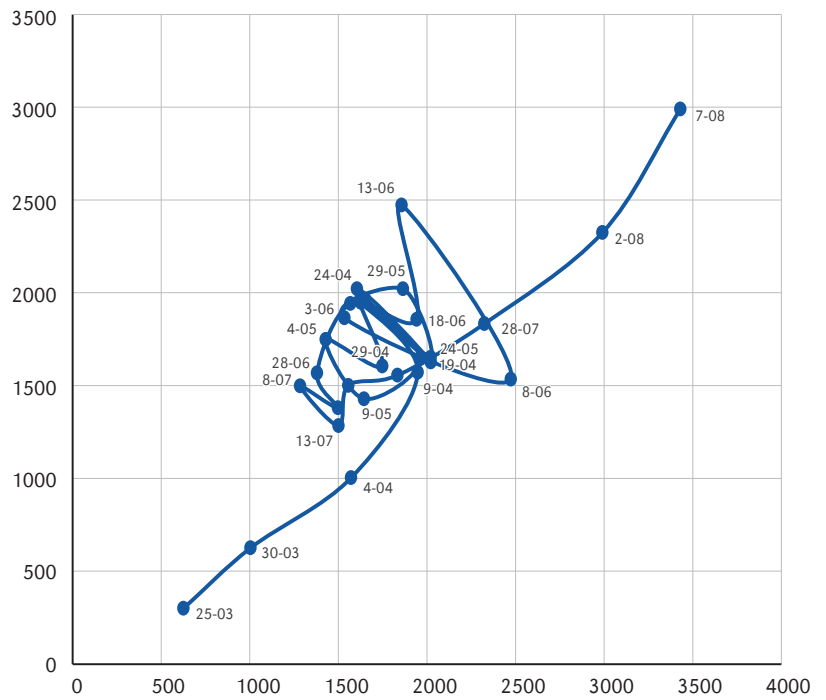

Figure 8. The development trajectory of the COVID-19 epidemic in Poland in the period from March 15th to August 7th 2020

monotonic, extinction of the epidemic, excluding May 14th (222 infections). However, the situation reversed on July 8 th, which was followed by a further increase (up to 147) in the number of infections (Fig. 9). The mean level of infections for the study period was 2021, with a standard deviation of 1107 and a coefficient of variation of $54.8 \%$. 


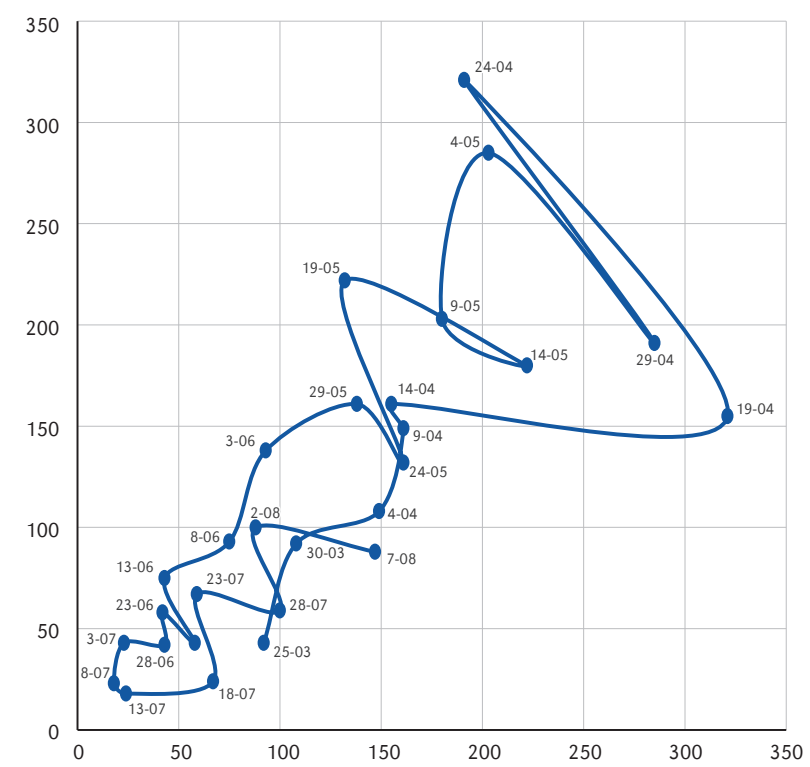

Figure 9. The development trajectory of the COVID-19 epidemic in the Dolnoślaskie Voivodeship in the period from March 15th to August 7th 2020

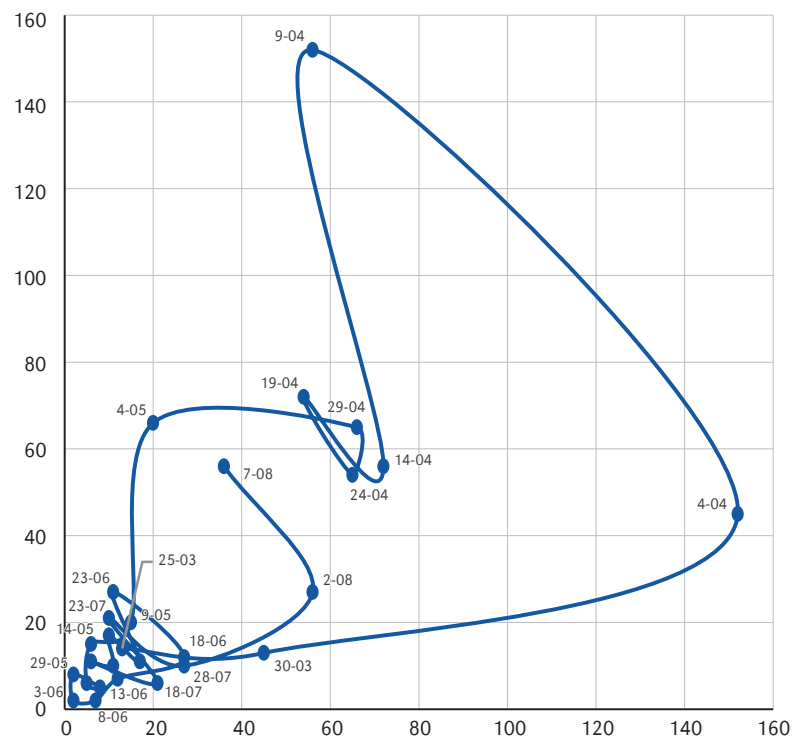

Figure 10. The development trajectory of the COVID-19 epidemic in the Kujawsko-Pomorskie Voivodeship in the period from March 15th to August 7th 2020

The trajectory of coronavirus infections in the Kujawsko-Pomorskie Voivodeship is specific (Fig. 10). The fairly sharp rise first peaked on April 4th (152 infections) followed by a gradual decline to 2 people per day (May 29th and June $3 \mathrm{rd}$ ). In the days that followed, however, they increased again, 27 people on June 18th, followed by a gradual decline. 
In a sense, in the initial phase of the epidemic, yet especially in the final phase, the situation can be said to have been stable, although on July 18th there was another increase in the number of infections, slightly smaller than in previous periods. The average level of infections during the study period was 518 , with a standard deviation of 236 and a coefficient of variation of $45.6 \%$.

The looped trajectory for the Lubelskie Voivodeship indicates the cyclical nature of the epidemic, in which, after the period of increase in the number of infections, a decrease occurs, followed by yet another increase (Fig. 11). Contrary to the previous voivodeships, it is difficult to talk about the extinction of the epidemic, but rather a relapse, especially in the last pentads. The average level of infections for the period between March 15th - August 7th was 489 , with a standard deviation of 287 and a coefficient of variation of $58.7 \%$.

As for the region with the lowest number of infections, the epidemic in the Lubuskie Voivodeship started from a relatively high level (Fig. 12). The number of infections continued to increase until April 4th (20 cases), after that it began to gradually decline, indicating no case on May 14th and May 19th. After the latter date, however, an increase in infections (11 people each) was recorded on May 24th and 29th, followed by a monotonic decrease until July 8th. The following pentads saw an increase in the number of infections, four times the maximum from the beginning of the epidemic. The trajectory marked a "great loop", perhaps a new phase of the epidemic development (Fig. 12). The mean level of infections for the study period was 124, with a standard deviation of 117 and a coefficient of variation of $80.7 \%$.

The course of the epidemic in the Łódzkie Voivodeship is cyclical. Until April 9th, there was an increase in infections (up to 173 cases), followed by a period of some relative stabilization of the level, lasting until May 4th (132 infections). Thereafter, until May 19th, there was a decrease in infections (90 people), followed by an increase, reaching a maximum level on June 8th (417 infections). From that date on, a gradual, monotonic decrease in the number of infections has been

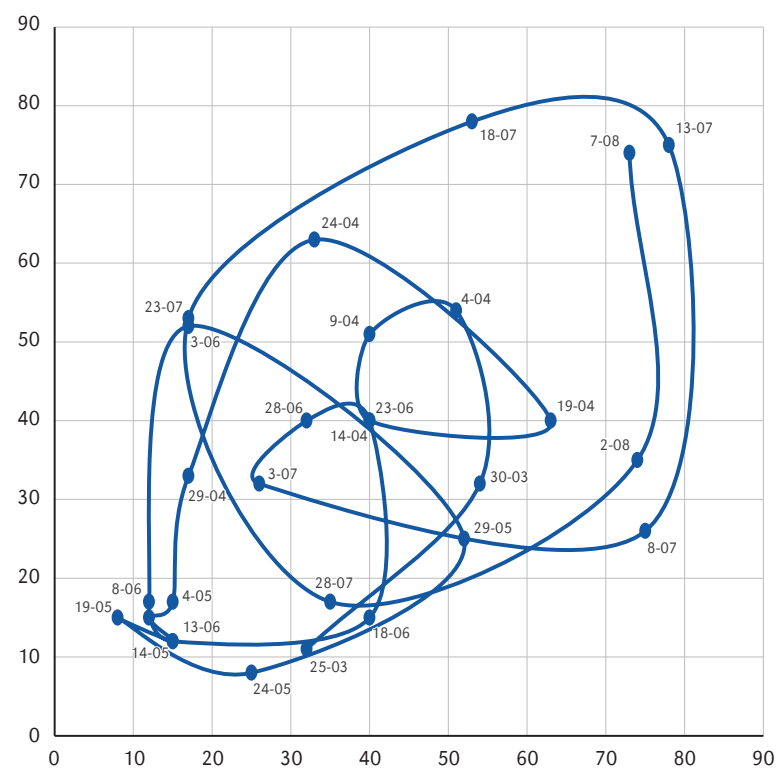

Figure 11. The development trajectory of the COVID-19 epidemic in the Lubelskie Voivodeship in the period from March 15th to August 7th 2020 
observed, however with an increase from July 8 th. Despite the persistently relatively high level of infections, the situation seems to be gradually returning to the level of the beginning of the epidemic. There are two culminations of infections (with the second remaining), separated by a period of decline (Fig. 13). The average level of infections was

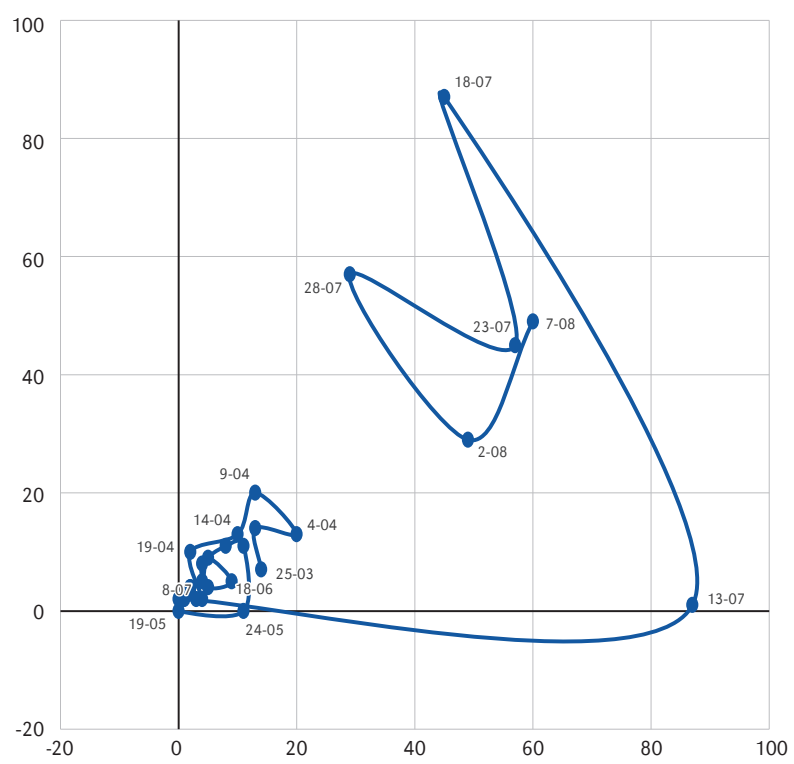

Figure 12. The development trajectory of the COVID-19 epidemic in the Lubuskie Voivodeship in the period from March 15th to August 7th 2020

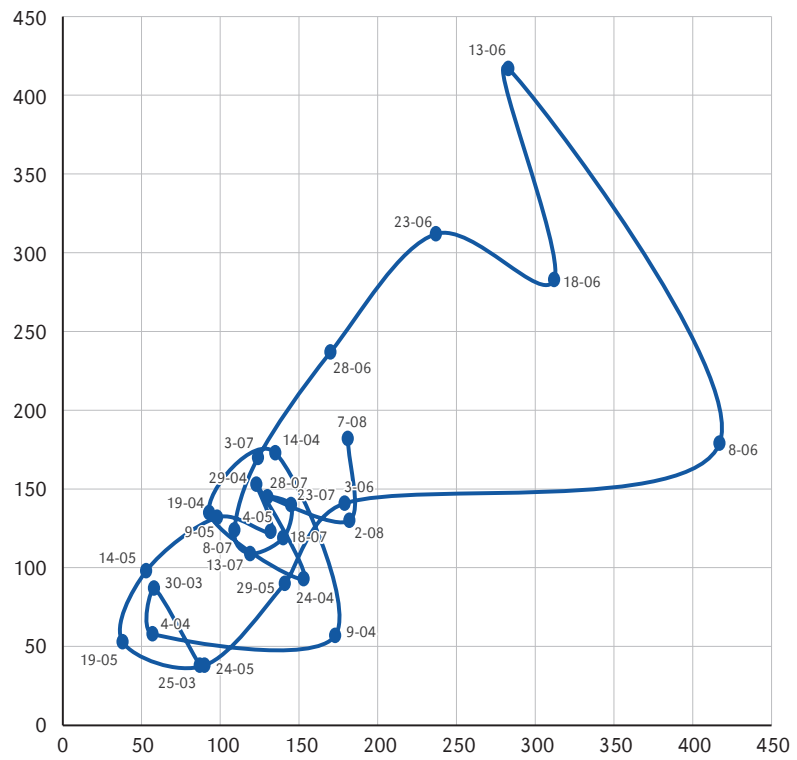

Figure 13. The development trajectory of the COVID-19 epidemic in the Łódzkie Voivodeship in the period from March 15th to August 7th 2020 
1860, with a standard deviation of 1354 and a coefficient of variation of $72.8 \%$.

The course of the epidemic in the Małopolskie Voivodeship is specific. Quite quickly, as of April 4th, the highest number of infections was recorded (173) and this high level continued to last for a month, until May 4th (100 infections). After that date, until May 29th, there was a gradual decrease in the number of infections (23), to reach the second maximum (132 infections) very quickly, on June 8th. Unfortunately, after the decline in the number of infections, on July $3 \mathrm{rd}$, a period of dynamic increase in infections began, which, took the form of a monotonic increase, on August ${ }^{2 n d}$, and reached the level of 545 infections, thus exceeding the previous maximum three times. Also, this situation indicates a new phase of epidemic development in this voivodeship (Fig. 14). The average level of infections in the study period was 1389, with a standard deviation of 1047 and a coefficient of variation of $75.4 \%$.

The culmination of infections in the Mazowieckie Voivodeship occurred very quickly, already on April 9th (616 cases). In the following days, a decreasing, albeit changing, downward trend was formed, until June 13th, when the number of infections increased again (351 infections). From that day on, the number of new cases decreased again and the situation from May this year was back. However, from July 13th another period of the increase in infections was marked, which on August 7th reached a new peak (428 infections), although not as large as at the beginning of the epidemic (Fig. 15). The average level of infections in the period from March 15th to August 7th was 3424, with a standard deviation of 1991 and a coefficient of variation of $58.2 \%$.

The course of infections was more varied in the Opolskie Voivodeship, although the number was relatively low (Fig. 16). However, the epidemic showed some kind of cyclicality which was documented by the looping of the trajectory. Up until April 14th, there was a slow increase in the number of infections (81 cases), followed by a decrease (37 cases) by May 29th and alternating increases and decreases. On July 8th, the situation apparently returned to its original

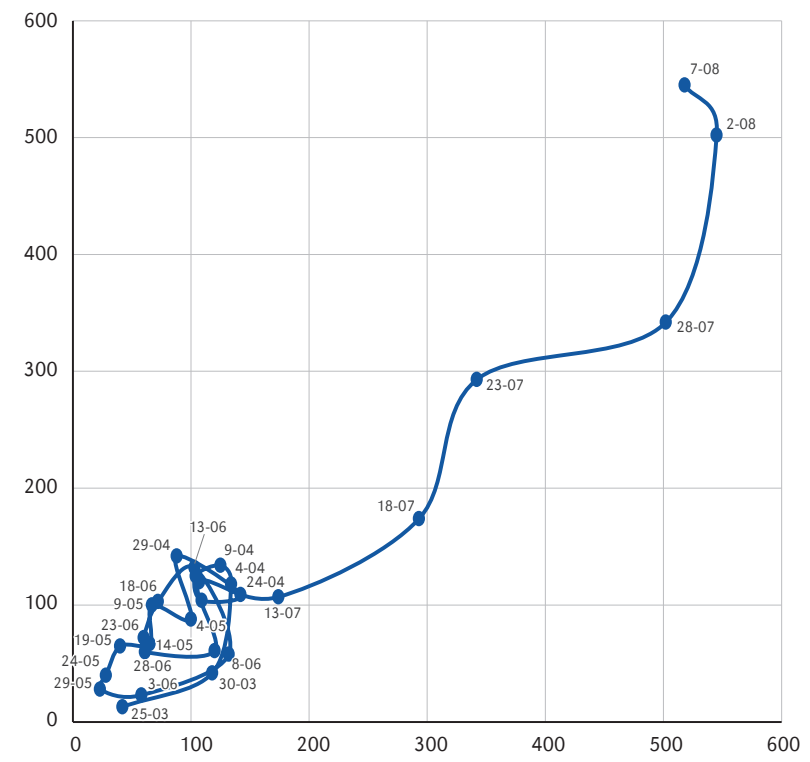

Figure 14. The development trajectory of the COVID-19 epidemic in the Małopolskie Voivodeship in the period from March 15th to August 7th 2020 


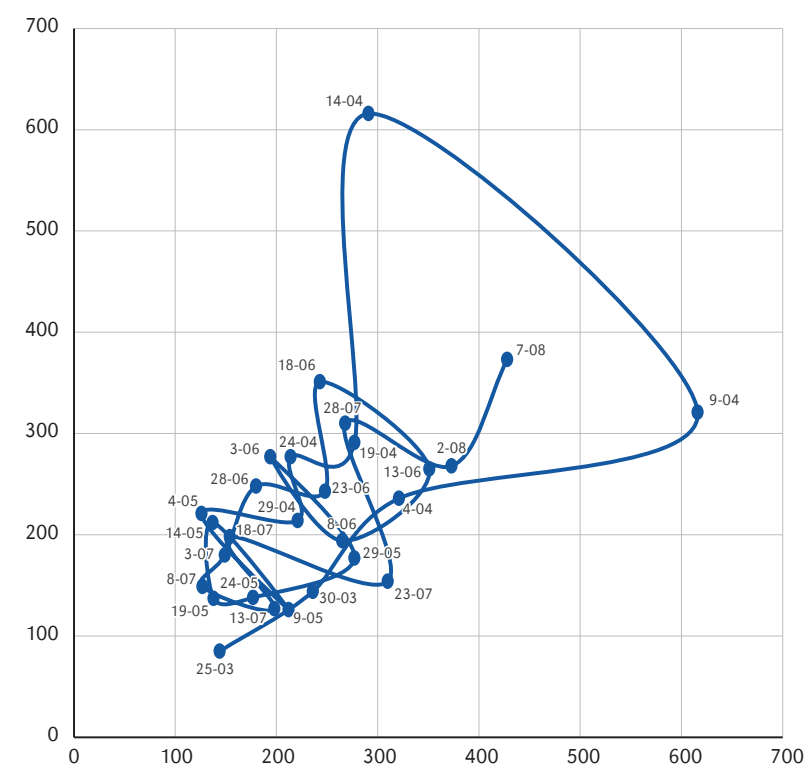

Figure 15. The development trajectory of the COVID-19 epidemic in the Mazowieckie Voivodeship in the period from March 15th to August 7th 2020

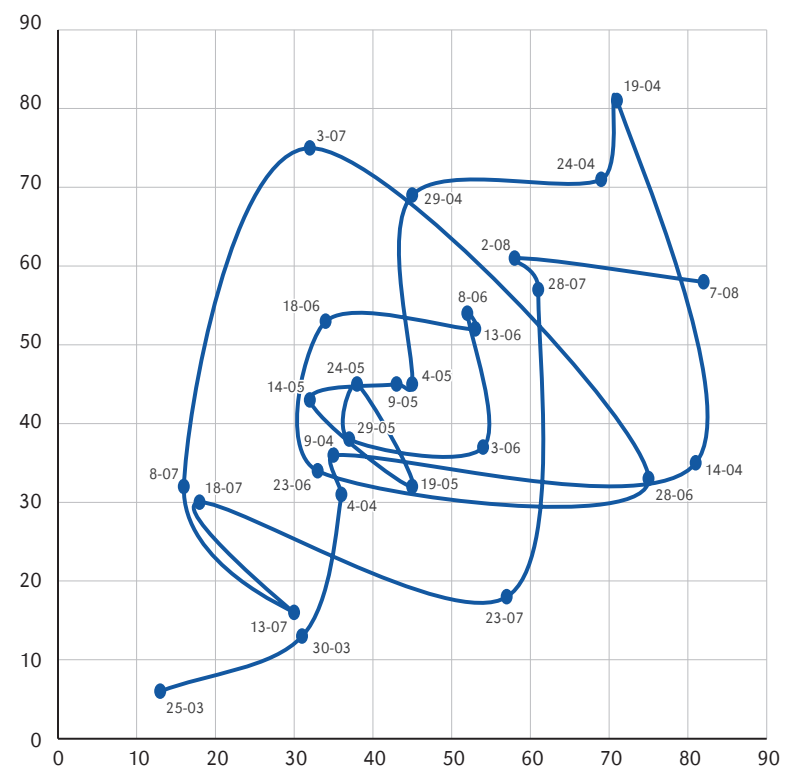

Figure 16. The development trajectory of the COVID-19 epidemic in the Opolskie Voivodeship in the period from March 15th to August 7th 2020

state. After that date, however, there was a renewed increase in infections, up to the maximum (82) on August 7th, which may also indicate a new phase or recurrence of the epidemic. The average incidence rate in the study period was 609, with a standard deviation of 388 and a coefficient of variation of $63.7 \%$. 
There was a relatively rapid increase in the number of infections in the Podkarpackie Voivodeship, culminating on April 9th (58 cases), remaining at a similar level (with a slight decrease) until May 9th. After that day, there was a noticeable decrease, which lasted until June 8th, with only 1 infection on May 19th. On June 13th, however, there was a rapid increase in infections (49 cases), which was the beginning of the greatest epidemic dynamics in this region (140 infections). After a slight decrease in the level of the epidemic development, its second, dynamic phase began (Fig. 17). The average incidence rate in the study period was 518, with a standard deviation of 400 and a coefficient of variation of $77.2 \%$.

The trajectory for the Podlaskie Voivodeship shows two clear loops indicating two phases of the epidemic development and the likely beginning of the third phase. The first culminated in 88 infections on April 14th and the second culminated in 77 infections on June 23rd and with a slow decrease. After July 18th, a new increase in the number of infections began, however not as large as at the beginning of the epidemic (Fig. 18). The epidemic in this region is clearly cyclical. The average incidence rate in the study was 508, with a standard deviation of 324 and a coefficient of variation of $63.8 \%$.

The trajectory for the Pomorskie Voivodeship shows a specific course (Fig. 19). A disturbance in the generally low level of infections is the sudden increase on April 29th (168 cases). The looping of the trajectory at a low level of infection indicates that there is no clear trend in the development of the epidemic. The upward trend did not begin until July 8 th, when the increase in infections became monotonic. The average level of infections for the study period was 484 , with a standard deviation of 283 and a coefficient of variation of $58.7 \%$.

The Ślaskie Voivodeship is the region in which the highest number of infections was recorded from the first stage of the epidemic development (Fig. 20). The looping of the trajectory proves the variability of the epidemic development trend with the maximum number of infections in the period from May 14th (1306 cases) to June 8th (1299 cases). After that date, there was a gradual, monotonic decrease in the number of infections, yet at the highest level in the country. As of July 13th, the numbers increased again. The average level of infections in the research period was 7466 cases, with a standard deviation of 5893 and a coefficient of variation of $78.9 \%$.

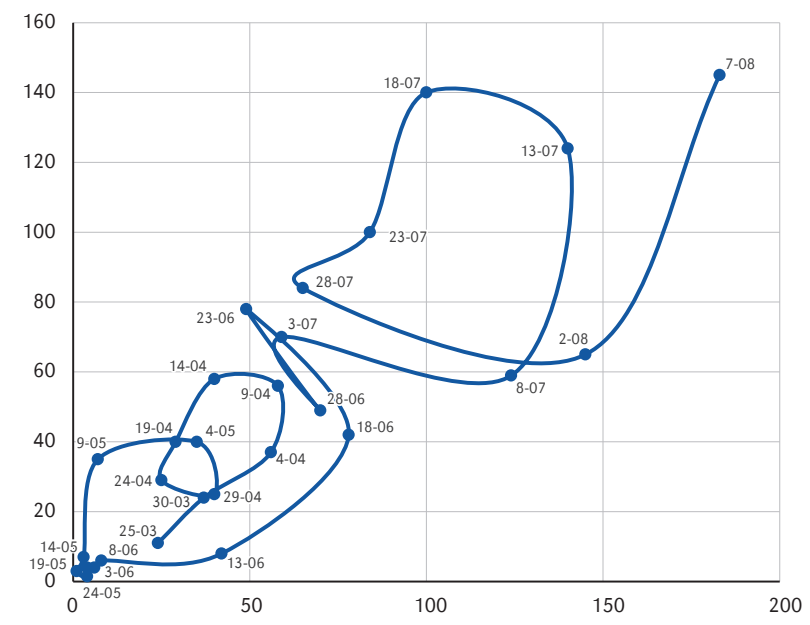

Figure 17. The development trajectory of the COVID-19 epidemic in the Podkarpackie Voivodeship in the period from March 15th to August 7th 2020 
Another type of trajectory loop can be observed in the Świętokrzyskie Voivodeship, which indicates the phasic character of the epidemic (looping), with slight changes, at a relatively low level on a national scale (Fig. 21). The highest number of infections was recorded on June 18th and August 7th (78 cases each). However, the increase in infections

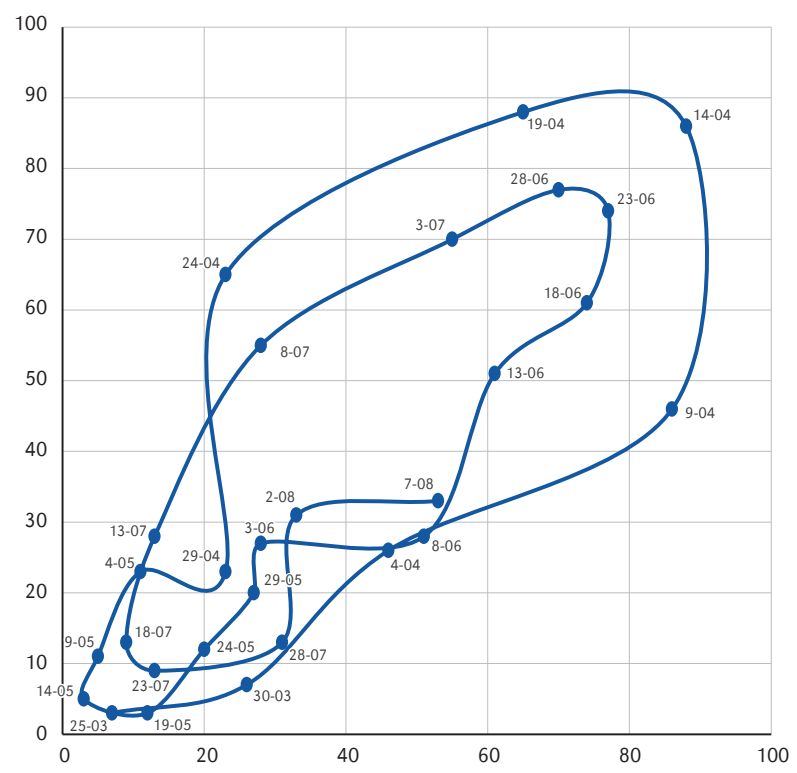

Figure 18. The development trajectory of the COVID-19 epidemic in the Podlaskie Voivodeship in the period from March 15th to August 7th 2020

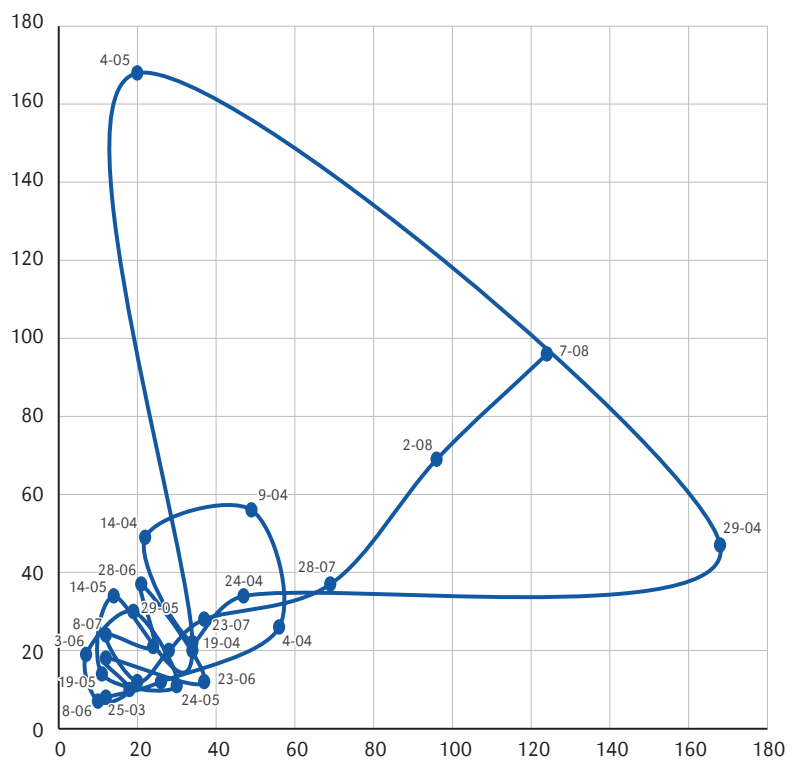

Figure 19. The development trajectory of the COVID-19 epidemic in the Pomorskie Voivodeship in the period from March 15th to August 7th 2020 
in the last pentads is not high. The average level of infections in the examined time frame was 481, with a standard deviation of 332 and a coefficient of variation of $69.0 \%$.
An even lower level of coronavirus infections took place in the Warmińsko-Mazurskie Voivodeship. However, the change in the number of new cases was periodic

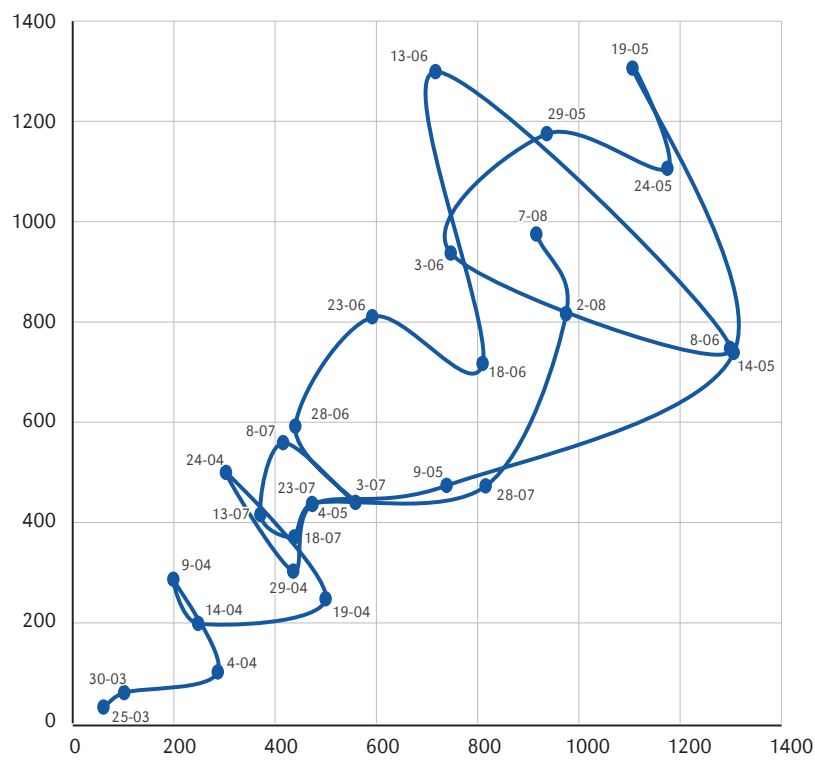

Figure 20. The development trajectory of the COVID-19 epidemic in the Ślaskie Voivodeship in the period from March 15th to August 7th 2020

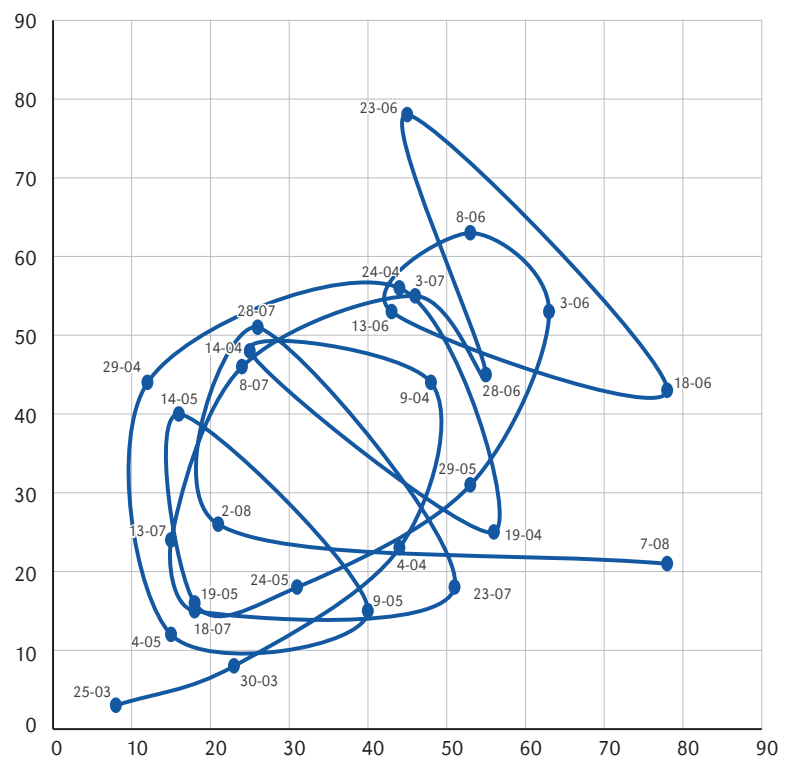

Figure 21. The development trajectory of the COVID-19 epidemic in the Świętokrzyskie Voivodeship in the period from March 15th to August 7th 2020 
(cyclical), which is reflected in the looping trajectory (Fig. 22). The spikes in infection were separated by a decrease, with zero levels on April 29th and June 3rd. On July 23rd, a period of gradual increase in the number of infections began. The average incidence rate in the study period was 188, with a standard deviation of 103 and a coefficient of variation of $54.7 \%$.

The periodicity of infections at a fairly high level, as for Polish conditions, is visible in the Wielkopolskie Voivodeship (Fig. 23). The highest number of infections was recorded at the beginning of the epidemic on April 19th

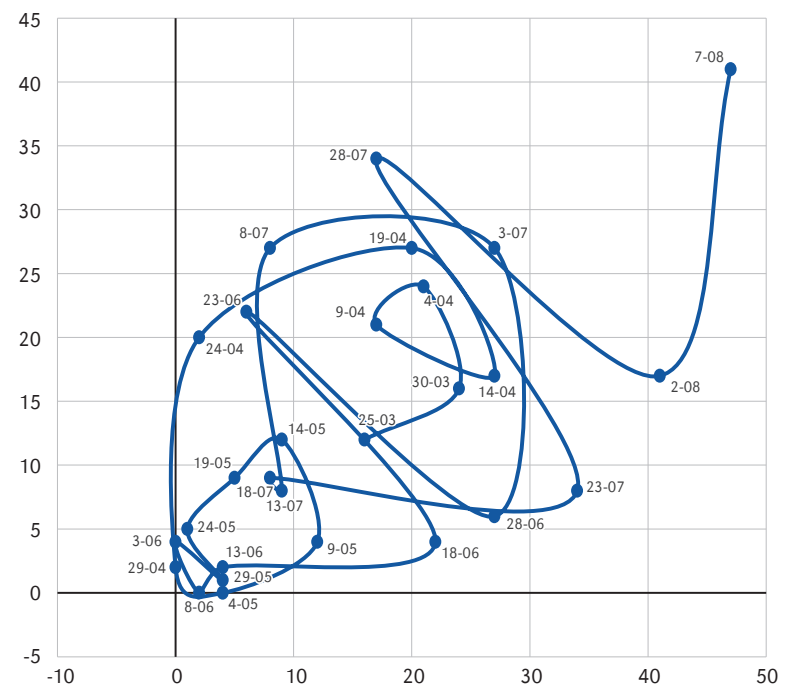

Figure 22. The development trajectory of the COVID-19 epidemic in the Warmińsko-Mazurskie Voivodeship in the period from March 15th to August 7th 2020

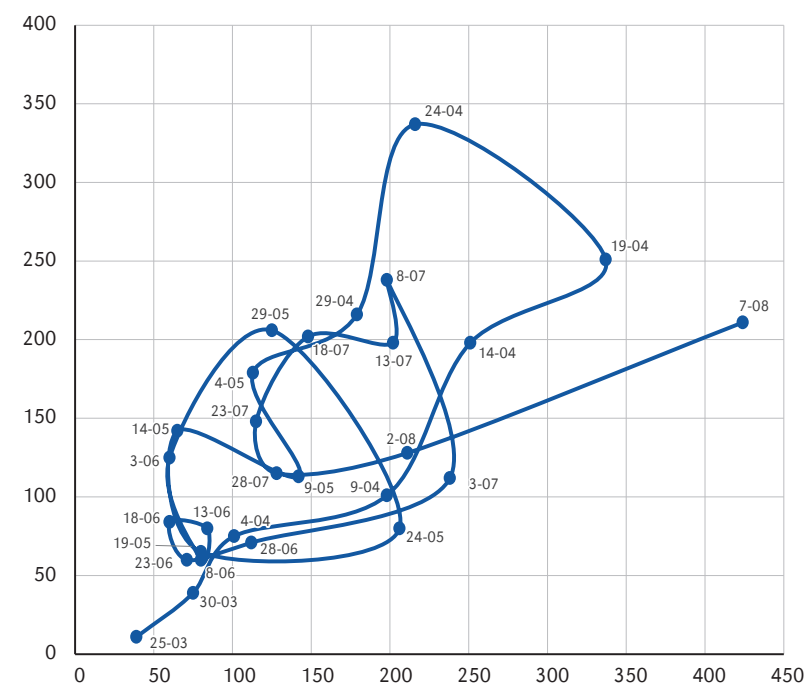

Figure 23. The development trajectory of the COVID-19 epidemic in the Wielkopolskie Voivodeship in the period from March 15th to August 7th 2020 


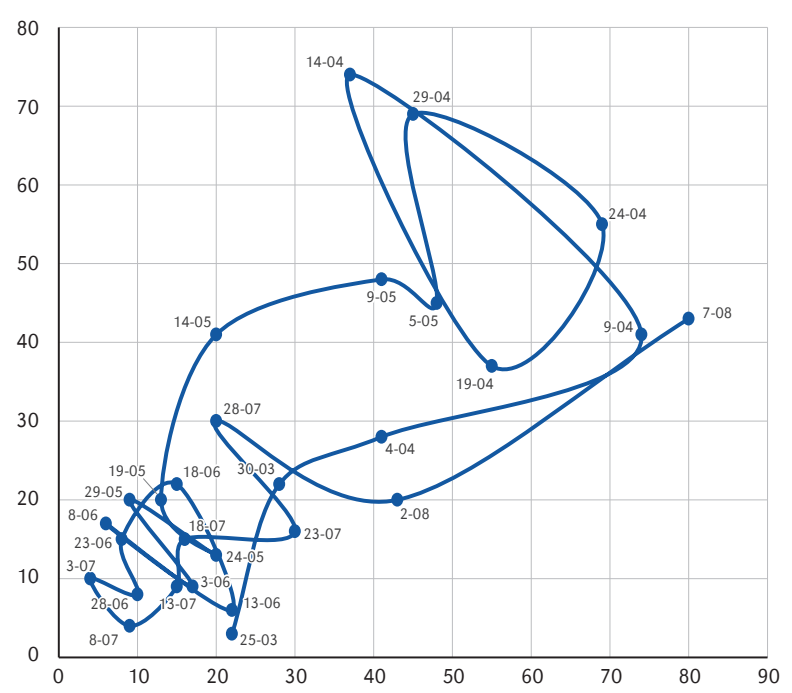

Figure 24. The development trajectory of the COVID-19 epidemic in the Zachodniopomorskie Voivodeship in the period from March 15th to August 7th 2020

(337 infections) and at the end of the study period (424 infections), suggesting a new wave of infections. The average level of infections in the period between March 15th - August 7th was 1946, with a standard deviation of 1221 and a coefficient of variation of $62.7 \%$.

The epidemic in the Zachodniopomorskie Voivodeship developed rather quickly, but it did not reach a very high level. The maximum number of cases was recorded on April 9th - 74 people. As in many other regions, it was periodic with a gradual decline in the number of cases, reaching a low and gradually declining level after June 13th, however lasting only until July 8 th. After that date, as in other voivodeships, another increase in the number of infections was recorded (Fig. 24). The average level of infections during the study period was 449, with a standard deviation of 233 and a coefficient of variation of $51.9 \%$.

Although some similarities can be seen in the course of the epidemic development in all the voivodeships, they do not take into account the size of infections nor the pace of the changes taking place. The similarity is very general and concerns only the general trends of change. This allows only to draw a conclusion about the individual character of the COVID-19 epidemic development processes in each voivodeship. Evidence supporting such a conclusion is the trajectory of the epidemic development in Poland, which as a result of individual (voivodeship) trends, shows no similarity to the trajectories of individual voivodeships. However, it is difficult to compare the graphical representations of ongoing processes with each other. For a more reliable determination of the degree of their similarity, other studies have been carried out, the results of which are presented in the next section of the study.

\section{The similarity of epidemic development processes}

As it has already been written, the correlation coefficient $^{3}$ was the measure of the similarity (not intensity) of the epidemic development processes in the individual regions

\footnotetext{
${ }^{3}$ Correlations were calculated between the series of data characterizing the epidemic development in individual voivodeships. A matrix of correlation coefficients with dimensions of $16 \times 16$ was obtained, showing the similarity structure of development processes, the generalization of which (the greatest dual similarity of voivodeships) is reflected in the obtained classifications.
} 
(voivodeships). Two classifications of similarity have been made: (1) for the increasing number of infections (every five days) and (2) for the increments in infections over five-day periods (pentads).

The applied method of elementary connections has led to the distinction of 5 classes of similarity of the epidemic development processes, namely: Class I - voivodeships: Wielkopolskie, Lubelskie and Podkarpackie; Class II - the Ślaskie, Mazowieckie and Opolskie voivodeships; Class III - voivodeships: Łódzkie, Świętokrzyskie and Podlaskie; Class IV voivodeships: Dolnośląskie, Kujawsko-Pomorskie and Warmińsko-Marurskie; Class $V$ - voivodeships: Małopolskie, Lubuskie, Pomorskie and Zachodniopomorskie. The spatial arrangement of the similarity classes resembles a mosaic, in which several clusters can be distinguished (Fig. 25). The largest, consisting of three voivodeships, is located in northwestern Poland. The similarity of the epidemic development processes within the given classes was relatively high $(r=0.990$; statistical significance at the level of $\alpha=0.0001$ ). The most similar in this respect were the following voivodeships: Lubelskie and Podkarpackie $(r=0.998)$, Mazowieckie and Małopolskie ( $r=0.997)$, as well as Mazowieckie and Ślaskie ( $r=0.996)$, while the most dissimilar were Lubelskie and Podlaskie $(r=0.792)$, Małopolskie and Podlaskie ( $r=0.814)$, as well as Lubuskie and Łódzkie $(r=0.846)$. This similarity concerns the course of the processes, and not the number of infections, which varies within separate classes.

The same method was used to determine the similarity of the voivodeships from the point of view of the increase in infections in pentads. There are 3 classes of similarity, namely: class I - voivodeships: Małopolskie, Lubuskie, Lubelskie, Podkarpackie and Warmińsko-Mazurskie; Class II - voivodeships: Opolskie, Wielkopolskie, Zachodniopomorskie, Kujawsko-Pomorskie, Dolnoślaskie, Pomorskie and Mazowieckie; Class III - voivodeships: Podlaskie, Świętokrzyskie, Łódzkie and Ślaskie. Also, these classes do not form compact clusters, however, in general, it may

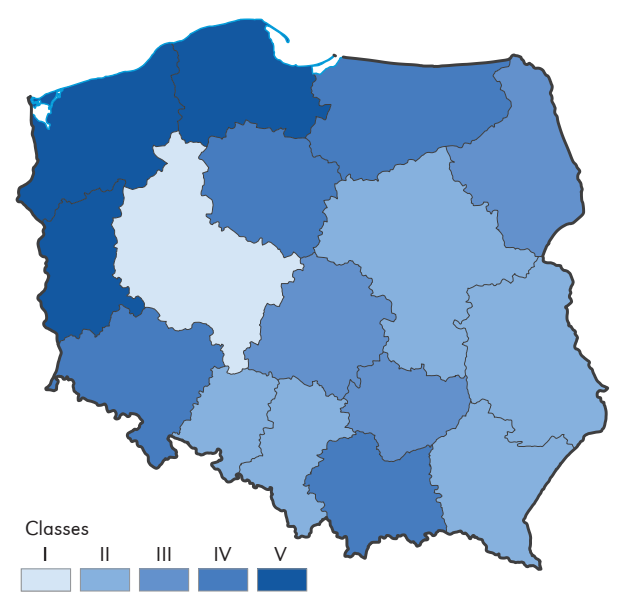

Figure 25. The similarity of the processes of epidemic development in Poland from a regional perspective in the period from March 15th to August 7th 2020 (based on the increasing number of infections in pentads [every five days], using the correlation coefficient)

be assumed that one of such clusters is located in the north-west, the second in the southeast, and the third in the central and southern part of the country (Fig. 26). However, the similarity of the voivodeships in this respect was not high ( $r>0.500$; significance at the level of $\alpha=0.05$ ). The voivodeships which were the most similar in this regard include: Lubuskie and Podkarpackie $(r=0.741)$, Lubelskie and Podkarpackie ( $r=0.738)$, and Podkarpackie and Małopolskie $(r=0.717)$, while the following voivodeships were definitely dissimilar: Śląskie and Kujawsko-Pomorskie $(r=-0.372)$, Dolnośląskie and Podkarpackie $(r=-0.352)$, Dolnośląskie and Łódzkie $(r=-0.308)$ as well as Dolnoślaskie and Lubuskie $(r=-0.287)$. The Ślaskie Voivodeship, the most similar to the Łódzkie Voivodeship, yet with a relatively low degree of similarity $(r=0.335)$, and Lower Silesia (negative correlation coefficients, as the measures of dissimilarity), showed a clear specificity of the increase in the number of infections.

It can therefore be assumed that the high similarity of the epidemic development processes in the individual voivodeships in the period between March 15th - August 7th was accompanied by a relatively low similarity 
of the increase in infections in the given pentads. Although the plotted trajectories indicate an extremely complicated process of the epidemic development in individual voivodeships, one can notice some similarity within the classes, as indicated by the obtained classifications.

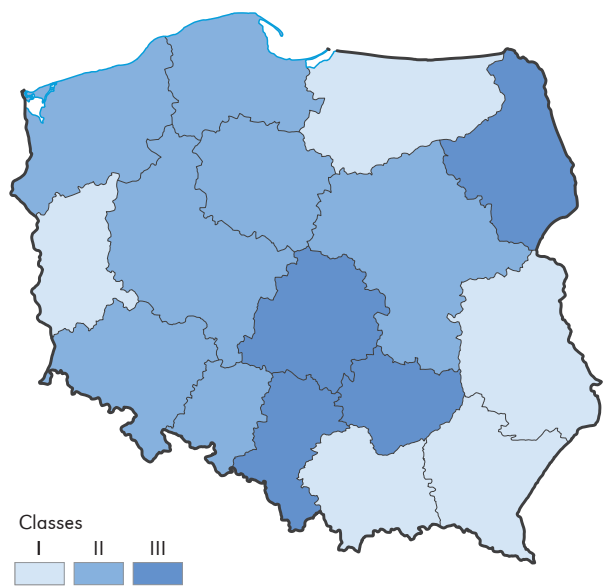

Figure 26. The similarity of the processes of epidemic spread in Poland from a regional perspective in the period from March 15th to August 7th 2020 (based on the increase in infections in pentads [over five days], using the correlation coefficient)

\section{An attempt to identify the factors of epidemic differentiation on a regional scale (multivariate regression correlation analysis)}

In an attempt to indicate the factors which could possibly have an impact on the regional differentiation of the level of infections, an unquestionable regularity was adopted, namely that the cause of the diffusion (transmission) of the infection is direct contact between an infected person and a person free from infection. This meant taking into account those characteristics which could in some way indicate situations, in which direct contact might occur. Characteristics which may indicate favorable or counteractive circumstances for becoming infected and falling ill have also been taken into account. These factors were to be indicated by correlation analysis, and their impact was to be determined by multivariate regression. The analysis took into account the characteristics related to the level of infections, which was the number of SARS-CoV-2 infections on July 1st per 1000 inhabitants in the individual voivodeships, and, as it has already been written, the characteristics related in some way to the factors favoring infections or limiting infections and disease. The following characteristics which can be considered as conducive to infection, as they indicate potential interpersonal contact, were taken into account: $\left(x_{1}\right)$ population density, $\left(x_{2}\right)$ percentage of urban population $\left(x_{4}\right)$ number of people working in industry, $\left(x_{3}\right)$ professional activity and $\left(x_{11}\right)$ remuneration (greater likelihood of using goods and services). Among the characteristics which weaken immunity, the following were taken into account: $\left(x_{5}\right)$ percentage of the population beyond retirement age or susceptible to disease, e.g. $\left(\mathrm{x}_{7}\right)$ contracting infectious diseases, $\left(\mathrm{x}_{6}\right)$ beds in care and treatment institutions, nursing homes and hospices, and $\left(x_{8}\right)$ deaths to infectious and parasitic diseases, as well as such characteristics which should to some extent limit incidence, such as $\left(x_{9}\right)$ number of inhabitants per 1 hospital bed (probable negative correlation) and $\left(x_{10}\right)$ number of passenger cars (restrictions on the use of public transport). ${ }^{4}$

The analysis of the correlation showed that the number of infections is positively correlated at the significance level $\alpha=0.001$ only with reference to characteristic $\left(\mathrm{x}_{1}\right)$ population density $\left(r=0.8175 ; R^{2}=66.83 \%\right)$, at the level of $\alpha=0.01$ with characteristic: $\left(x_{4}\right)$ employment in industry per 1000 inhabitants $\left(r=0.6214 ; R^{2}=38.61 \%\right)$ and negatively with characteristic $\left(x_{9}\right)$ the number of inhabitants

4 In these studies, unfortunately, the characteristic of the number of inhabitants per 1 hospital bed was adopted as the measure of the level of development of the financial base of inpatient treatment (indirectly of health care). The financial base defined in this way must be treated as a stimulant of incidence. This dictated a specific interpretation of the effect of this characteristic in the regression equations and the correlation coefficient. 
per 1 hospital bed $\left(r=-0.5987 ; R^{2}=35.84 \%\right)^{5}$ At the significance level $\alpha=0.05$, the following characteristics were correlated with the number of infections: $\left(x_{2}\right)$ percentage of urban population $(r=0.5320),\left(x_{5}\right)$ percentage of the population beyond retirement age $(r=0.5320),\left(x_{3}\right)$ working people per 1000 inhabitants $(r=0.4901)$ and $\left(x_{10}\right)$ cars per 1000 inhabitants $(r=0.5149)$. The calculated correlation coefficients, as favorable factors for infections, allow to see those characteristics which clearly indicate the theoretically greater possibility of interpersonal contact. These include population density, especially in cities, and professional activity, especially in industry. Infections are also favored by advanced age and susceptibility to infectious diseases. On the other hand, they are counteracted by the financial base of the health service (negative correlation coefficient of the number of cases with the characteristic: number of inhabitants per 1 hospital bed). Unfortunately, unlike public transport, car use facilitates contact, and hence contagion, rather than reduces it. Social welfare homes and other similar care and treatment facilities do not have a major impact on infections, on a national scale. In the light of these studies, which are quite limited in scope, the thesis confirms that the epidemic can only be limited by limiting interpersonal contact and taking appropriate precautions (washing hands, wearing masks). Unfortunately, the obtained results also point to workplaces (professional activity) as the potential (also documented by sanitary services) outbreaks of infections, especially in industrial plants.

The regression analysis has been performed in two variants. In the first variant, the total number of infections on July 1st was the dependent variable and in the second, it was the new infections on the same day. The explanatory variables (independent variables) were the above mentioned 11 characteristics.

5 The negative correlation indicates the influence (positive) of the underdevelopment of the financial base of inpatient treatment on the incidence level.
In the first variant (the dependent variable - the number of infections cumulatively), the final result took the form of a regression equation, in which the value of the dependent variable, the total number of infections per 1000 inhabitants, is significantly shaped $\left(R^{2}=87.9 \%\right)$ by the four characteristics which have been taken into account. This equation is:

$$
\begin{aligned}
y= & -1.5347+0.0004 x_{1}+0.0122 x_{4}+ \\
& 0.1316 x_{5}-0.0089 x_{9} .
\end{aligned}
$$

This means that the level of infections in Poland in the period from March 15th to July 1st, 2020 was shaped by: population density $\left(\mathrm{x}_{1}\right)$, people working in industry $\left(x_{4}\right)$, the population beyond retirement age $\left(x_{5}\right)$ and the poorly developed financial base of inpatient treatment $\left(x_{9}\right)$.

In the second variant, the final result was adopted as a regression equation, in which the value of the dependent variable (the number of infections per 1000 inhabitants on July 1st) is less significantly influenced $\left(R^{2}=50.55 \%\right)$, also by four characteristics, yet slightly different ones than in the case of the first variant. The regression equation took the following form:

$$
\begin{aligned}
y= & 0.1757+0.0002 x_{1}-0.0006 x_{2}- \\
& 0.0003 x_{6}-0.0005 x_{9} .
\end{aligned}
$$

This means that the level of coronavirus infections in Poland on July 1st, 2020 was positively influenced by: population density $\left(x_{1}\right)$ and a poorly developed financial base of treatment $\left(x_{9}\right)$, i.e. the number of people per 1 hospital bed, as well as negatively influenced by the following characteristics: percentage of urban population $\left(\mathrm{x}_{2}\right)$ and beds in nursing homes, hospices and health care facilities $\left(x_{6}\right)$, which is somewhat of a surprise. The above-mentioned facilities were considered centers of epidemic development.

The comparison of the two obtained results allows for the following general conclusions to be drawn: (1) the set of characteristics which has been taken into account, much better describes the level of infections during the epidemic from March 15th to July 1st than on a specific day, ie July 1st; (2) 
the characteristics describing the level of infections over a longer period of time, confirm the generally expressed view that frequent contact, which can be treated as a function of population density, employment in large production plants (industrial plants), and old age, are conducive to the development of the epidemic. In this respect, the developed base of inpatient treatment is inhibiting; (3) the regularity determined for a longer period of time is not confirmed by data for a specific day, which may mean that in specific situations the level of infections may be influenced by various characteristics. In both time perspectives, however, the population density and the financial base of inpatient treatment have the same impact.

\section{Conclusion}

The aim of the conducted research was to show the space-time aspects of the development of the COVID-19 epidemic in Poland. This goal was achieved through a series of studies. These studies concerned, among other things: the general characteristics of the infections in Poland in the first phase of the spread of the epidemic, the determination of differences in the intensity of infections, the trajectory of the course of the epidemic in the country and particular voivodeships, the examination of the degree of similarity in the course of epidemic development, and attempts to indicate factors that could influence the different intensity and development dynamics of the SARS-CoV-2 virus infections across regions.

In the light of the conducted research, it can be stated as follows:

1. The SARS-CoV-2 coronavirus epidemic develops up until August 7th, 2020 in a monotonic manner, yet with different increases in infections on individual days (in the case of the research - in pentads). The most populated regions of the country are characterized by the highest number of infections (Tab. 1). The degree of disease concentration in the five most populated voivodeships keeps gradually increasing, although in a decreasing manner. A particularly high number of infections is characteristic of the Ślaskie Voivodeship which is densely populated, with a large number of jobs where many people work in the same workplace (especially in mines). The dynamics of the increase of new infections month by month, however, is gradually decreasing. Since July 8 th, the number of new infections has been systematically increasing in pentads, which may indicate a new phase of epidemic development, which could be caused by the holiday period and the accompanying mobility of the inhabitants, and it is not out of the question that it may also be the effect of removing restrictions.

2. A more reliable indicator (than the number of infections) of the level of infection of the inhabitants of particular voivodeships with the virus, is the comparison of this number to the number of inhabitants, which in this study is referred to as viral infection intensity. Appropriate classifications in this respect have been made for five time cuts. Summarizing the results of the study, it should be stated that in each time cut, a different classification of voivodeships was obtained. A constant level of low infection intensity during the study period is shown in the following voivodeships: Lubuskie, Podkarpackie and Pomorskie, and to a lesser extent Kujawsko-Pomorskie, Lubelskie and Warmińsko-Mazurskie. The average level of infections is maintained in the Małopolskie Voivodeship, while a high level - generally in the Ślaskie and Łódzkie Voivodeships. In the Dolnośląskie and Mazowieckie Voivodeships, there is a noticeable decrease in the intensity of infections and its stabilization at an average level, as is the case in the following voivodeships: Opolskie, Pomorskie and Wielkopolskie. In the Zachodniopomorskie Voivodeship the intensity changes alternately from low to average. Summarizing these studies, it should be stated that the epidemic constitutes a very serious problem in the Ślaskie and ŁódzkieVoivodeships, 
and a serious problem in the Dolnoślaskie, Mazowieckie, Opolskie, Podlaskie, Świętokrzyskie, Wielkopolskie and Zachodniopomorskie voivodeships. Resulting from the conducted research, the rather random in terms of spatial dimension, development of the epidemic, does not allow indicating reliable factors of the intensity of infections or formulating accurate forecasts, although situations conducive to infection and the behavior of the inhabitants may change the described state in the future (cf. point 5).

3. The development of the epidemic in the individual voivodeships is, however, characterized by different dynamics. Class I - very stable development dynamics is represented by the following voivodeships: Dolnośląskie, Kujawsko-Pomorskie, Warmińsko-Mazurskie and Zachodniopomorskie; Class II - stable dynamics is achieved in the following voivodeships: Lubelskie, Mazowieckie and Pomorskie; Class III - average stability of dynamics is represented by the following voivodeships: Opolskie, Podlaskie, Świętokrzyskie and Wielkopolskie; Class IV - unstable dynamics, voivodeships: Łódzkie and Małopolskie; Class V - very unstable dynamics is achieved in the following voivodeships: Lubuskie, Podkarpackie and Ślaskie. This classification shows no correlation either with the size of infections or their severity and is extremely random.

4. The process of epidemic development in individual voivodeships is graphically illustrated by the plotted trajectories. The similarity of the epidemic development trajectory in individual voivodeships is very general and concerns only general development trends and changes. Therefore, one can speak of an individual character of the development processes of the COVID-19 epidemic in each of the voivodeships. Certain proof of this statement is the trajectory of the epidemic development in Poland, which, as a result of individual trends, does not show any similarity to the trajectories of individual voivodeships (see point 6, including figures).
5. The similarity of the epidemic development processes made it possible to better define (dimension) the conducted classification. Five classes of similarity of the epidemic development processes have been distinguished, namely: Class I - voivodeships: Wielkopolskie, Lubelskie and Podkarpackie; Class II - Śląskie, Mazowieckie and Opolskie Voivodeships; Class III - voivodeships: Łódzkie, Świętokrzyskie and Podlaskie; Class IV - voivodeships: Dolnośląskie, Kujawsko-Pomorskie and Warmińsko-Marurskie; Class V - voivodeships: Małopolskie, Lubuskie, Pomorskie and Zachodniopomorskie. The similarity of the epidemic development processes within separate classes was relatively high (cf. point 7). This type of classification complements the graphic image of the development processes shown by the trajectories (see point 6). It should be emphasised, however, that this is not a similarity of the intensity of the epidemic development process but of the dynamics. The similarity of the voivodeships was also determined in terms of the increase in infections. There are 3 classes of similarity, namely: class I - voivodeships: Małopolskie, Lubuskie, Lubelskie, Podkarpackie and Warmińsko-Marurskie; Class II - voivodeships: Opolskie, Wielkopolskie, Zachodniopomorskie, Kujawsko-Pomorskie, Dolnośląkie, Pomorskie and Mazowieckie; Class III - voivodeships: Podlaskie, Świętokrzyskie, Łódzkie and Ślaskie. However, the similarity of the voivodeships in this respect was not high (see point 7). In this case the similarity also does not apply to absolute values of the infection rate increase, but to dynamics.

6. Searching for factors affecting the regional differentiation of the level of virus infections, it was found that the level of infections in Poland in the period from March 15th to July 1st 2020 was positively influenced by: population density, people working in industry, people beyond retirement age and a poorly developed financial base of inpatient care. It can be therefore assumed that what was conducive 
to the development of the epidemic were interpersonal contacts, theoretically more frequent in densely populated areas and in workplaces with a large number of employees (so-called outbreaks of infections), as well as shortcomings in the development level of material and personal health care base. On the other hand, the level of coronavirus infections on July 1st 2020 was influenced positively by: population density and a poorly developed financial base of medical care (number of people per 1 hospital bed), as well as negatively by the following characteristics: the percentage of the urban population and the number of beds in nursing homes, hospices and care facilities, which is somewhat of a surprise. The influence of population density and underdevelopment of medical base on the infection level is acceptable. However, it is difficult to apply this to the care facilities mentioned, which were considered outbreaks of the epidemic. The conducted research, on the one hand, confirms the influence on the level of infections in the process of epidemic development of characteristics related to activeness and interpersonal contact, as well as the financial base of medical care, and on the other hand, they indicate the random influence of characteristics in the case of specific days. In both variants of the study, the level of infection was influenced by population density and the financial base of health service (see point 8). Certainly, a more authoritative variable considered to be a factor behind epidemic development would be population mobility, as well as the function of this mobility, which is distance. Reasonable studies in this field can be conducted, as it seems, only in small spatial scales (city, poviat, commune, or alternatively agglomeration) using big data analysis, in this case related to the registration of the location of mobile phones and on this basis only physical distance, not identical, however, with social distance, can be determined (Fuchs, 2020).
Summarizing the obtained results, it can be stated that the epidemic is in constant development, yet the dynamics of the overall number of infections is on the decrease. However, this does not apply to the increments which have been growing since the beginning of July. This may indicate a new phase of the epidemic. The development of the epidemic in each of the voivodeships has its own characteristic course, although there are some similarities. However, they refer to the "shape" of the process, not the number of infections or their intensity. The resultant of the regional development trajectories is the trajectory for Poland, which indicates the general monotonic development of the epidemic until April 19th, stabilization of the situation by June 8th, suppression of the development until July 8th and its new phase after that date. A much better indicator than the absolute number of infections, which may prove helpful in shaping prevention and the policy of fighting epidemics, is the number of infections compared to the number of inhabitants. The following factors are conducive to infections: population density, employment in industry, old age, also a poorly developed financial base of medical care (generally as an indicator of the level of health care development), and to a lesser extent professional activity. The influence of these factors can be related to interpersonal contact, the dimension of which is opportunity, frequency and the so-called social distance. There is also, however, something like virus immunity, determined by general health, specifically metabolic and immunological systems, often changing with health, age, nutrition, physical fitness, obesity, treated and untreated diseases, and probably many other factors the influence of which may be very individual in nature (Śliwowska 2020). It may be worth taking this opportunity to assume that factors determining epidemics are in a sense systemic, and the main elements of such a system are, as already indicated, geographically differentiated: infection, vulnerability, interdependency, immunization, resilience, blame and health care (Sparke, 
Angulelov 2020). Unfortunately, the research carried out is only indicative. For the number of diagnosed infections is highly dependent on the tests performed. This type of obvious dependence is indicated by the incidences reported by the Ministry of Health in relation to the number of tests performed. As the number of detected infections increases with the number of tests performed. It seems, however, that despite these doubts, the conducted research resulted in a certain picture of the regional differentiation in the development of the SARS-CoV-2 virus epidemic in Poland across voivodeships in the period from 15 March to 7 August 2020, i.e. the development in time and space.

Editors' note:

Unless otherwise stated, the sources of tables and figures are the authors', on the basis of their own research.

\section{References}

Corner, L.A. (1994). Postmortem diagnosis of Mycobacterium bovis infection in cattle. Veterinary Microbiology, 40(1-2), 53-63. https://doi.org/10.1016/0378-1135(94)90046-9

Domański, R. (1990a). Gospodarka przestrzenna. Warszawa: Wydawnictwo Naukowe PWN.

Domański, R. (1990b). Zasady geografii społeczno-ekonomicznej. Warszawa-Poznań: Wydawnictwo Naukowe PWN.

Hägerstrandt, T. (1969). Innovation diffusion as a spatial process. Chicago-London: The University of Chicago Press.

Haggett, P. (1965). Locational analysis in human geography. London: Edward Arnold.

Haggett, P., Cliff, A.D., Frey, A. (1977). Locational methods. London: Edward Arnold.

Hellwig, Z. (1968). Zastosowanie metody taksonomicznej do podziału krajów ze względu na na poziom ich rozwoju oraz zasoby i strukturę wykwalifikowanych kadr. Przeglad Statystyczny, 15(4), 307-327.

Hingel, A.J. (1993). Note on 'A new model of European development': Innovation, technological development and Network-led integration. Brussels: Commission of the European Communities.

Jarynowski, A., Wójta-Kempa, M., Płatek, D., Krzowski, Ł., Belik, V. (2020). Mobilność, jako kluczowa zmienna wyjaśniająca regionalne zróżnicowanie w dynamice zakażeń. Wyniki wstępne. https://depot.ceon.pl/handle/123456789/18444

Kamiński, Z. (1982). Przestrzenna dyfuzja innowacji rolniczych. Poznań: Wydawnictwo Naukowe UAM.

Kretowicz, P. (2013). Nowe podejścia badawcze w geografii zdrowia w literaturze anglosaskiej. Przeglad Geograficzny, 85(4), 549-571. https://doi.org/10.7163/PrzG.2013.4.3

Lance, G.N., Williams, W.T. (1967). Computer programs for hierarchical polythetic classification ("Similarity Analyses"). The Computer Journal, 9(1), 60-64. https://doi.org/10.1093/comjnl/9.1.60

Łoboda, J. (1983). Rozwój koncepcji i modeli przestrzennej dyfuzji innowacji. Wrocław: Wydawnictwo Uniwersytetu Wrocławskiego.

Mellacher, P. (2020). COVID-Town: An integrated economic-epidemiological agent-based model. https://arxiv.org/abs/2011.06289v1

Ormerod, P. (1993). Notes on unemployment. Paper presented at Unemployment Conference at Wiston House, Sussex (September 1993), London.

Parysek, J. (1982). Modele klasyfikacji w geografii. Poznań: Wydawnictwo Naukowe Uniwersytetu im. A. Mickiewicza w Poznaniu.

Parysek, J. (1997). Podstawy gospodarki lokalnej. Poznań: Wydawnictwo Naukowe Uniwersytetu im. A. Mickiewicza w Poznaniu. 
Parysek, J. (2002). Metropolises and processes of metropolisation. Geographia Polonica, 75(1), 25-42.

Parysek, J. (2004). Trajektorie rozwoju miast polskich w latach 1992-2002. In: J. Parysek (Ed.), Rozwój regionalny i lokalny w Polsce w latach 1989-2002 (pp. 117-132). Poznań: Bogucki Wydawnictwo Naukowe.

Parysek, J. (2006). Wprowadzenie do gospodarki przestrzennej. Poznań: Wydawnictwo Naukowe Uniwersytetu im. A. Mickiewicza w Poznaniu.

Parysek, J., Mierzejewska, L. (2012). Trajectories of the demographic development of Poland after 1999. Bulletin of Geography. Socio-Economic Series, 17, 109-125.

Pisano, C. (2020). Strategies for post-COVID cities: An insight to Paris En Commun and Milano 2020. Sustainability, 12, 1-16. https://doi.org/10.3390/su12155883

Pred, A. (1977). The choreography of existence. Comment s on Hagerstrand's time geography and its usefulness. Economic Geography, 52(2), 207-221.

Rogalski, M., Dadel M., Sobkowska K., Rusinek B., Sikorski, M., Kowal M., Tarnowski, P., Supko, W., Dziedzic, T., Zespół BIQ Data Wyborcza. (2020). Dane o COVID-19 według powiatów. https://bit.ly/covid19_powiaty

Śleszyński, P. (2020). Prawidłowości przebiegu dyfuzji przestrzennej rejestrowanych zakażeń koronawirusem SARS-CoV-2 w Polsce w pierwszych 100 dniach epidemii. Czasopismo Geograficzne, 91(1-2), 5-18.

Steinhausen, D., Langer, K. (1977). Clusteranalyse: Einführung in Methoden und Verfahren der automatischen Klassifikation; mit zahlreichen Algorithmen, Fortran-Programmen, Anwendungsbeispielen und einer Kurzdarstellung der multivariaten statistischen Verfahren. Berlin-New York: Walter de Gruyter. 